\title{
Import Competition from and Offshoring to Low-Income Countries: Implications for Employment and Wages at U.S. Domestic Manufacturers
}

\author{
by \\ Fariha Kamal \\ U.S. Census Bureau \\ Mary E. Lovely \\ Department of Economics \\ Syracuse University
}

CES 17-31 March, 2017

The research program of the Center for Economic Studies (CES) produces a wide range of economic analyses to improve the statistical programs of the U.S. Census Bureau. Many of these analyses take the form of CES research papers. The papers have not undergone the review accorded Census Bureau publications and no endorsement should be inferred. Any opinions and conclusions expressed herein are those of the author(s) and do not necessarily represent the views of the U.S. Census Bureau. All results have been reviewed to ensure that no confidential information is disclosed. Republication in whole or part must be cleared with the authors.

To obtain information about the series, see www.census.gov/ces or contact J. David Brown, Editor, Discussion Papers, U.S. Census Bureau, Center for Economic Studies 5K034A, 4600 Silver Hill Road, Washington, DC 20233, CES.Working.Papers@census.gov. To subscribe to the series, please click here. 


\begin{abstract}
Using confidential linked firm-level trade transactions and census data between 1997 and 2012, we provide new evidence on how American firms without foreign affiliates adjust employment and wages as they adapt to import competition from low-income countries. We provide stylized facts on the input sourcing strategies of these domestic firms, contrasting them with multinationals operating in the same industry. We then investigate how changes in firm input purchases from low-income countries as well as domestic market import penetration from these sources are correlated with changes in employment and wages at surviving domestic firms. Greater offshoring by domestic firms from low-income countries correlates with larger declines in manufacturing employment and in the average production workers' wage. Given the negative association, however, the estimated magnitudes are small, even for a narrow measure of offshoring that includes only intermediate goods. Import penetration of U.S. markets from these sources is associated with relatively larger changes in employment for arm's length importing firms, but has no significant correlation with employment changes at firms that do not trade. Given differences in the degree of both offshoring and import penetration, we find substantial variation across industries in the magnitude of changes associated with low-income country imports.
\end{abstract}

Keyword: import competition, offshoring, U.S. manufacturing, employment, wages

JEL Classification: F14, F16, F66, L25, L60, J31

\footnotetext{
*Any opinions and conclusions expressed herein are those of the authors and do not necessarily represent the views of the U.S. Census Bureau. All results have been reviewed to ensure that no confidential information is disclosed.
} 


\section{Introduction}

The growth of imports from low-income countries has sparked national debate over its impact on the U.S. manufacturing sector, which has shed jobs while charting consistent output growth. After holding steady at about 17 million jobs through the 1990s, manufacturing employment dropped by 6.2 million between 1997 and 2012. This rapid decline in the number of manufacturing jobs coincided with rising levels and shares of U.S. imports of manufactured goods from low-income countries - those countries with per capita incomes only a fraction of the American level. Over the period, U.S. imports from low-income countries rose steadily as a share of domestic consumption, from less than 7 percent in 1997 to almost 21 percent by $2012 .{ }^{1}$

Sophisticated analyses support the popular belief that import competition from countries with lower income, especially China, is a significant driver of losses in U.S. manufacturing employment. Acemoglu et al. (2016) seek to explain employment losses at the industry level, focusing on import competition from China. Their central estimates suggest job losses from rising Chinese import competition in the range of 2.0-2.4 million over the period 1999 to 2011. Looking at the national labor market, Pierce and Schott (2016) again focus on imports from China but link manufacturing job losses after 2000 to a U.S. policy change rather than Chinese supply growth. They find that industries for which the granting of permanent Most Favored Nation status to China resolved uncertainty about larger future US tariff rates experienced greater employment loss.

Despite this bleak picture of how trade with low-income countries influences American manufacturing jobs, not all observers see a direct relation between changes in trade patterns and employment. Edwards and Lawrence (2013) show that the decline in U.S. manufacturing employment has been remarkably predictable since 1960 and argue that there is little to suggest

\footnotetext{
${ }^{1}$ Sources and additional data on U.S. import patterns are provided below.
} 
that something fundamental has changed in the relationship between manufacturing employment and job trends, even though manufactured imports from low-income countries have grown. They also find that the level and decline in the US manufacturing employment shares is similar to trends in other industrial countries, including those with large manufacturing trade surpluses.

While these analyses are motivated by the growth in manufactured goods imports from low-income countries, they do not distinguish between imports that compete with U.S.-made goods generally and "offshore outsourcing," direct purchases of foreign-made inputs by U.S. firms. This approach ignores the important linkages between fragmentation of production processes and the growth in low-income manufactured imports. As found by Pierce and Schott (2016) using Chinese Customs data, the strongest relationship between changes in U.S. tariff policy and Chinese export growth is for foreign-owned firms operating in China. Moreover, they find that trade volumes in industries liberalized by the granting of permanent normal trade relations rose for both general exports and for processing exports. This evidence is consistent with important links between production fragmentation, direct investment by developed country firms, and the import surge from low-income sources.

This paper documents contemporaneous movements in U.S. manufacturing employment and wage and import competition in the form of final goods, on the one hand, and firm offshore outsourcing, on the other. We measure "import competition" as economy-wide, industry-specific import penetration. Changes in import penetration capture the pressure on American producers when wholesalers and retailers make imported products available to consumers on final markets. To measure offshoring, we create a broad and a narrow measure of imported inputs, both using confidential firm-level trade transactions. Because we are able to create separate measures of import penetration and offshoring, we are able to record the co-movements of employment and 
wages with each of these dimensions of competitive pressure from the growth of low-incomecountry export competency.

Offshore outsourcing reflects the trading activities of firms themselves, and its predicted impact on employment is thought to be more complicated than that of import penetration generally. Firms may use offshore outsourcing as a substitute for domestic production of certain inputs, leading to domestic lay-offs. At the same time, imported intermediates may allow domestic firms to compete successfully with imported final goods by lowering production costs. Surviving firms may then be able to expand production domestically while shifting their employment mix away from production workers and toward non-production and headquarter employment. In this way, production workers' wages as well as relative labor shares may be affected by offshore outsourcing.

Considering the multiple margins along which firms adjust to competition from lowincome countries, this paper focuses on manufacturing firms that do not trade with foreign affiliates - that is, we focus on domestic firms rather than multinational firms. These less-globallyengaged enterprises account for 95\% of manufacturing firms and employ about half of American manufacturing employment. Unlike larger and more productive multinational enterprises, domestic firms cannot move employment to overseas affiliates to reduce costs. ${ }^{2}$ Replacing domestically produced inputs with foreign-sourced inputs requires that these firms import intermediate goods directly. ${ }^{3}$ Unlike multinationals, whose trade patterns reflect affiliate locations and activities as well as U.S. based production activity, trade patterns of non-multinational domestic firms reveal changes in their U.S. operations only.

\footnotetext{
${ }^{2}$ However, even in this case, movement of jobs offshore may have a net positive effect on U.S. based employment if it allows multinational firms to reduce costs and expand global sales.

${ }^{3}$ Bernard et al. (2015) provide a framework for understanding the multiple dimensions along which multinationals operate and use it to interpret features of U.S. trade transactions data.
} 
With access to confidential matched firm-level production and trade datasets, we focus on this narrowly defined set of U.S. firms to better understand the dynamics of manufacturing employment and their relation to offshoring and import penetration. Defining domestic firms as those that do not engage in trade with foreign affiliates, we investigate how employment changes correlate with growth in offshore outsourcing, measured by firms direct importing activity, and with growth in the share of foreign-made goods sold on the U.S. market. We are able to compare the response to import competition of these arm's length importers with the response of firms that do not trade at all, but which also experience competition from imports on final-goods markets.

Because we are interested in how changes in offshore outsourcing substitute for domestic employment, we limit our analysis to firms that survive over a 5-year interval, allowing us to observe changes in both firm-level trade transactions and firm-level employment. Undoubtedly, and as found by Bernard, Jensen, and Schott (2006) for the period 1977 to 1997, import competition causes some firms to cease production in the United States over each five-year interval, leading to larger job losses than we observe in surviving firms alone. By focusing on surviving firms, however, we are able to see if there is evidence of substitution between imported intermediates and domestic employment. This approach also allows us to dig deeper to see whether employment adjustments differentially affect production and non-production workers at surviving domestic firms.

We now turn to an overview of recent theoretical and empirical explorations of the impact of product market competition and of offshoring on domestic employment. We focus on how recent theoretical and data access advances illuminate the multiple margins along which a firm may respond to foreign supply shocks. We then provide updated information on employment changes and import patterns through 2012, with details on multinational firms and those firms with 
less global engagement. The fourth section describes our estimating specification and how we construct measures of import competition and offshoring. Regression results are reported next, both for arm's length importing firms and for non-trading firms. We conclude by considering how these results advance our understanding of the changes occurring in U.S. manufacturing.

\section{Import Competition and Offshoring: Theory and Predictions}

The surprisingly rapid decline in U.S. manufacturing employment has heightened interest in the relationship between international trade and domestic labor markets, particularly the role of imported goods and whether these goods compete with or complement local production. This interest has been spurred, to a large extent, by the growing importance of low-income-country manufactured exports, whose share had been fairly small prior to the mid-nineties. This rise in the share of imports has been led by China, which accounted for 89 percent of the growth in U.S. imports from low-income countries between 2000 and 2007 (Autor, Dorn, and Hanson, 2013).

The rise in imports includes not only final goods, as comparative advantage between the U.S. and low-income countries predicts, but also intermediate goods. Intermediate inputs include parts and materials to make products for consumption both domestically and abroad. A wave of outsourcing and offshoring to low-income countries accelerated the growth in imports of intermediate goods by advanced economies (Hummels, Ishii, and Yi, 2001). Globalization permits firms to fragment the production processes into sequential stages and allows low-income countries to specialize in various stages of production. How these changes in global production patterns have affected employment and wages in developed countries is an area of active research.

\subsection{Import competition and employment}

The Heckscher-Ohlin (HO) model predicts that countries will export products that use its abundant factor of production intensively and import products that use its scarce factors 
intensively. Thus, import competition from low-income countries, which are relatively more labor abundant than the U.S., will impact U.S. firms in industries that are traditionally more laborintensive (such as apparel and textile) differently from U.S. firms in industries that are traditionally more capital-intensive (machinery). The intuition from the HO model suggests that capitalabundant countries will experience resource reallocation from labor-intensive to more capitalintensive industries.

This prediction is directly tested using data for U.S. manufacturing establishments by Bernard, Jensen, and Schott (2006). They find that industry level import competition from lowincome countries induces multiple dimensions of reallocation within and across industries. Across industries, greater exposure to total imports from low-income countries disproportionately lowers plant employment growth and the probability of survival. Within industries, capital intensive plants tend to perform better relative to labor intensive plants when faced with higher exposure to low-income country imports. The authors estimate that about 14 percent of the aggregate decline in manufacturing employment between 1977 and 1997 was due to rising low-income country import competition. They also find that plants facing higher exposure are more likely to switch to industries that face lower exposure, suggesting strategic adaptation by U.S. firms.

In an analysis of more recent data, Cooke, Kemeny, and Rigby (2014) extend Bernard, Jensen, and Schott's (2006) analysis to study the impact of imports from low-income countries on U.S. manufacturing employment changes between 1992 and 2007, allowing for differential effects by worker skill levels. The authors find that workers with less than a high school degree experienced greater job losses due to low-income country import competition than did workers with at least a college degree. 
There is special interest in the relationship between import competition from China and the aggregate decline in U.S. manufacturing employment during the last fifteen years. Acemoglu, Autor, Dorn, Hanson, and Price (2016) estimate that a 1 percentage point rise in Chinese import competition reduced domestic manufacturing industry employment by 1.3 percentage points. Autor, Dorn, and Hanson (2013) examine the effect of Chinese import competition on local U.S. labor markets. They find that import competition explains a quarter of the contemporaneous aggregate decline in U.S. manufacturing employment between 2000 and 2007. They also find that transfer benefits payments for unemployment, disability, retirement, and healthcare increase in regions more exposed to Chinese trade competition. Interestingly, they find that transfer benefits such as Trade Adjustment Assistance (TAA), which specifically provides benefits to workers who have been displaced by trade shocks, accounts for an insignificant share of trade-induced increases in transfers. This may be suggestive of industry-wide import competition affecting workers differently than offshoring, a distinction they do not explore.

\subsection{Offshoring and employment}

Offshoring, primarily measured as imports by firms of intermediate goods, may exert countervailing forces on employment. On the one hand, greater foreign competitiveness allows firms that source from abroad to have access to cheaper intermediate inputs that can increase firm productivity. As a result, unit costs may decrease and output and employment may increase. On the other hand, cheaper intermediate inputs may substitute for domestic labor, particularly, unskilled labor, and thus may result in decreased employment. Empirical assessments of the relationship between offshoring and employment have evolved with the availability of data. The

first set of papers used industry level data to measure both employment and offshoring. A second wave of research took advantage of confidential access to firm level measures of offshoring and 
employment. With the advent of matched employer-employee datasets, some recent work combines worker level data with firm level measures of offshoring. ${ }^{4}$

Feenstra and Hanson (1999) pioneered the measurement of offshoring using industry data. They create two measures of offshoring - broad and narrow - to tease out impacts of input trade on the relative wage of non-production workers in U.S. manufacturing. Because they did not have access to firms' trade transactions, to create these offshoring measures they combined data on total U.S. imports and exports by 4-digit SIC industry with detailed information on material purchases from the Census of Manufactures. They estimate the share of inputs purchased offshore using the share of imports in domestic absorption in each industry. Their broad offshoring measure captures all inputs purchased by a firm, including raw materials. Their narrow offshoring measure only includes imported inputs purchased within the firm's industry classification. The logic in restricting to the firm's industry is that the more similar inputs are to output, the more likely it is that the firm could have produced that input in-house. In various specifications of a two-stage estimating procedure, they find that offshoring has an economically meaningful effect on the relative non-production wage, but that computer expenditures, a measure of high-tech capital investment, accounts for substantially more of the observed increase in within-industry inequality.

Hsieh and Woo (2005) use both broad and narrow measures of offshoring to study how offshoring to China affected the demand for skilled labor in Hong Kong from 1976 to 1996. They find that offshoring to China is capable of explaining about half of the increase in the demand for skilled labor. Amiti and Wei (2009) look at employment declines through the lens of labor productivity. Emphasizing the role of services offshoring, they estimate that this form of importing

\footnotetext{
${ }^{4}$ See Hummels, Munch, and Xiang (2016) for an excellent review of the labor market effects of offshoring.
} 
accounts for $10 \%$ of the growth in labor productivity of U.S. manufacturing industries between 1992 and 2000, while finding that material offshoring has an insignificant impact.

The increased availability of firm-level data has made it possible to explore within-industry firm heterogeneity in responses to both industry-wide import competition and offshoring shocks. Biscourp and Kramarz (2007) use data on French manufacturing firms and explicitly distinguish between firm imports in final goods products in the same industry as the firm (narrow offshoring) and all other imports (broad minus narrow offshoring). They find that a rise in offshoring, measured as final goods imports in the firm's industry, is correlated with a fall in employment at French firms. Use of firm level data makes clear that changes are occurring within firms and not only across firms. Mion and Zhu (2013) find that offshoring to China as well as industry wide import penetration from China leads to skill upgrading at surviving Belgian firms between 1996 and 2007. Hummels, Jørgensen, Munch, and Xiang (2014) combine worker level data with firm level trade transactions data to find that offshoring lowers the wages of low skilled workers while raising the wages of high skilled workers within job spells at Danish manufacturing firms.

Our analysis is similar to Mion and Zhu (2013) in that we also distinguish between firmlevel offshoring and industry-wide import penetration. Unlike their analysis, however, we focus on arm's length importers and non-trading firms only. By restricting attention to these firms, we explicitly exclude multinational firms from our analysis.

\subsection{Why multinationals are different}

Most globally engaged firms participate more intensively than domestic firms along every margin in the international economy (Bernard, Jensen, and Schott, 2009). Consequently, multinational firms have many ways to respond to a foreign supply shock. In a recent paper, Boehm, Flaaen, and Pandalai-Nayar (2015) document that establishments that became part of a 
multinational firm experienced job losses and increased foreign sourcing of intermediates by the parent firm. Thus, post-integration trade patterns reflect the affiliate activity long after the domestic employment loss. These relationships contrast with those of U.S. firms that trade at arm's length only, as well as non-traders, which can only respond to import shocks by adjusting domestic employment. Given these differences in response margins, we distinguish between multinational firms, arm's length importers, and non-traders. In our regression framework, we focus on the latter two groups to understand how this segment of U.S. manufacturers have adjusted employment and import patterns.

\section{Manufacturing Employment and Import Patterns since 1997}

Manufacturing employment in the United States was fairly stable for the three decades prior to 1997 (Scott, 2015). If we look at the share of manufacturing in total employment, however, a steady decline has been ongoing for decades. The manufacturing share of total nonfarm payrolls fell from 25 percent of the US workforce in 1970 to 14 percent by 1997. By 2012, this share had declined further, to about 9 percent of US employment. To provide additional details on trends in manufacturing employment and importing behavior since 1997, we use three confidential micro datasets from the U.S. Census Bureau. These combined sources allow us to observe how changes in employment track with firms' use of imported materials and competition with imports on US final-goods markets over four time periods: 1997, 2002, 2007, and 2012.

\subsection{Data Sources}

To conduct our empirical analysis, we combine data from the Census of Manufactures (CMF), the universe of import and export transactions from the Linked/Longitudinal Firm Trade Transactions Database (LFTTD), and the Longitudinal Business Database (LBD). We link the three datasets at the firm level using common firm identifiers. The CMF is a quinquennial survey 
of all establishments operating in the U.S. It collects information about the operation of the establishment including total value of shipments and use of capital, production and non-production workers, and materials. In using the CMF data, we implement two main data cleaning procedures. First, we restrict attention to observations that are used to produce official publications and those that are not derived from administrative records. ${ }^{5}$ Secondly, we use the concordance between NAICS codes over our sample period to assign each establishment a consistent industry code based on 2007 NAICS. ${ }^{6}$ Each establishment contains a firm identifier, which we use to aggregate both output and input information at the firm level. For single plant firms, the establishment and firm is synonymous. On average, $11 \%$ of firms in the data are multi-plant firms.

Merchandise trade transactions data for this study are drawn from the LFTTD. The LFTTD is a confidential database linking individual merchandise trade transactions to all U.S. firms that make them. The dataset contains detailed information for the universe of all import and export transactions at the ten-digit Harmonized Commodity Description and Coding System (commonly called Harmonized System or simply HS) valued at \$2,000 and \$2,500 or more, respectively. Information at the product level includes the value, quantity, date of the transaction, country of origin or destination, and if the transaction took place between related parties. ${ }^{7}$ The basis for the import transactions data is Form 7501 that U.S. Customs and Border Protection requires U.S.

\footnotetext{
${ }^{5}$ Starting in 2002, the CMF includes an indicator variable that identifies establishments that were used to produce official statistics. Although CMF is the universe of manufacturing establishments, data are only collected from establishments that were mailed forms. Very small establishments have their data imputed from administrative data.

${ }^{6}$ We use the concordance at https://www.census.gov/eos/www/naics/concordances/concordances.html. There were minor changes in the NAICS classification between 1997 and 2002 and 2002 and 2007 and a major change in classification between 2007 and 2012. We concord establishments on a 2007 NAICS basis.

${ }^{7}$ For exports, Foreign Trade Statistics Regulations, 30.7(v), define a related-party transaction as one between a U.S. exporter and a foreign consignee, where either party owns, directly or indirectly, 10 percent or more of the other party. For import, 19 U.S.C. $\$ 1401 \mathrm{a}(\mathrm{g})$ outlines seven different ways in which parties may be related in a U.S. import transaction. The ownership-based definition states firms are related if either owns, controls, or holds voting power equivalent to 5 percent of the outstanding voting stock or shares of the other organization.
} 
importers to fill out. ${ }^{8}$ The basis for the export transactions data is the Electronic Export Information (EEI). ${ }^{9}$ Of necessity, we merge 2011 trade transactions with firms in the 2012 CMF because the LFTTD is only available until 2011 at this time. We exclude firm-level trade in resource intensive products from our analysis in order to more closely focus on imported inputs that may substitute for domestic production. ${ }^{10}$

To characterize firms by trading status, we group them into five mutually exclusive, timeinvariant categories. We define a firm to be: (i) a multinational (MNC) if it conducted a related party transaction in any one of the four years, 1997, 2002, 2007, or 2012; (ii) an importer only if it only has arm's length import transactions and no export transactions in any of the sample years; (iii) an exporter only if it only has arm's length export transactions and no import transactions in any of the sample years; (iv) an importer and exporter if it conducts both export and import transactions at arm's length; and (v) a non-trader if it does not conduct any trade transaction, exports or imports, in any of the sample years.

Firm level measures of employment and age are constructed using the LBD, which consists of data on all existing establishments that have at least one paid employee in the U.S. non-farm, private economy (Jarmin and Miranda, 2002). We also identify the primary six-digit NAICS sector in which a firm operates. Since multi-establishment firms may operate in several sectors of the economy, the firm is considered to be operating in the sector that houses the largest share of its total employment. Finally, our analysis dataset (CM-LFTTD-LBD) consists of all firms in the U.S. economy that have at least one manufacturing plant. We have about 138,000 unique firms in the final sample spanning 1997 through 2012.

\footnotetext{
${ }^{8}$ See form http://forms.cbp.gov/pdf/cbp_form_7501.pdf.

${ }^{9}$ See http://www.census.gov/foreign-trade/aes/documentlibrary/aesparticipantsdata.html for the data elements.

${ }^{10}$ Resource intensive products are classified as 2-digit HS codes 1-10 (agricultural products), 25-27 (minerals), and 98 (special classification provisions). See https://hts.usitc.gov/current for detailed description of each HS chapter.
} 


\subsection{Manufacturing Employment Changes from 1997 to 2012}

Information, shown in Table 1, indicates that US manufacturing employment fell from over 17 million workers in 1997 to 10.8 million in 2012. Employment fell in each of the three 5-year intervals shown, although the relative decline slowed during the expansionary years between 2002 and 2007.

The overall decline in manufacturing employment was not equally distributed across all types of firms. Table 1 distinguishes firms by their international trading status. We define "multinationals" as those firms that engage in related-party trade. This group includes both American and foreign firms that trade with affiliates abroad. Manufacturing employment at multinationals, so defined, fell by 37 percent over the 15-year period, with the largest relative decline occurring in the period after 2007.

Firms that only trade at arm's length, including those firms that import but do not export and those that engage in both importing and exporting, shed manufacturing jobs at an even faster rate than did multinationals. Among firms that import but do not export, manufacturing employment fell by 38 percent between 1997 and 2012. Among firms that both import and export the decline was somewhat slower as their manufacturing employment fell by 30 percent over the 15-year period. Unlike multinationals, firms that trade at arm's length cut manufacturing jobs as rapidly before the new millennium than after. Although manufacturing employment declined for both types of firms in each of the 5-year intervals, the largest relative decline occurred between 1997 and 2002.

Firms that export but do not import also experienced large relative employment declines, with the number of manufacturing workers at such firms declining by 38 percent over the 15-year period. Between 1997 and 2002 alone, these firms shed about one-fifth of their total manufacturing 
employees. In comparison, firms that are not globally engaged through direct importing or exporting posted even larger manufacturing employment declines over the full period, with 42 percent fewer employees in 2012 than they had in 1997.

Table 2 shows similar numbers for total employment at firms with at least one manufacturing establishment. While total employment fell by 27 percent between 1997 and 2012, the decline was less than the 37 percent decline in manufacturing employment at the same set of firms. Consequently, manufacturing employment as a share of total employment for all firms fell from 56.3 percent in 1997 to 48.3 percent by 2012. The overall decline is dominated by the employment trends for multinationals, given their share of overall employment, as seen by comparing employment numbers in Tables 1 and 2. For multinationals, the manufacturing share of total employment fell from 50 percent in 1997 to 39.2 percent in 2012, showing a shift away from factory floor activities toward supporting activity and activity in other sectors. For firms engaged in arm's length importing, including both those that only import and those that import and export, the manufacturing share of employment actually rose slightly over the 15-year span, from 56.3 percent in 1997 to 57.4 percent in 2012. The manufacturing share of employment for firms that export but do not import rose from 68.1 percent to 71.9 percent, while the share for nontraders fell by almost10 percentage points to 69.5 percent.

Tables 3 and 4 confirm the well-known fact that multinational firms are a small share of the total number of manufacturing firms, but a large proportion of total manufacturing employment. These most globally engaged firms constitute only 4 percent of all manufacturing firms in 2012, but 51 percent of the manufacturing workforce. Arm’s length importers, both those that import only and those that both export and import, account for 19 percent of firms and 24 percent of manufacturing employment. Those firms that only export account for 21 percent of all 
firms, but only 12 percent of employment. The most common type of firm is those that do not trade, accounting for 55 percent of all manufacturing firms but housing only 13 percent of manufacturing employment.

Table 5 provides firm characteristics, averaged over all 4 years of data, for all firms and by trading status. These data reinforce the general understanding that larger firms are more globally engaged. Multinational firms are enormous relative to other types of firms, averaging 1087 employees and with 62 percent of firms having multiple establishments. Firms that engage in importing and exporting are the second largest, averaging 120 employees and with 22 percent having multiple establishments. In contrast, non-traders average only 21 employees and are very unlikely to have more than one establishment.

\subsection{Importing Patterns of Manufacturing Firms from 1997 to 2012}

Firm level import records provide insight into the sourcing patterns of U.S. based manufacturing firms. Table 6 shows the share of firm imports by source for multinationals and for firms that engage only in arm's length trade. In creating these shares, we exclude natural resource imports to gain a sense of where US firms source intermediates that could possibly substitute for US manufactured goods. The numbers in the table show the share of firm imports in each year sourced from each country group. Canada, Mexico, and the European Union are listed as separate sources, while we separate China from other "low-income" source countries. As in Bernard, Jensen, and Schott (2006), we classify a country as low-income if its per capita GDP is less than 5 percent of U.S. per capita GDP. We update the definition a bit by using GDP figures for 1997, the first year of our sample. ${ }^{11}$

\footnotetext{
${ }^{11}$ Bernard, Jensen, and Schott (2006) use 1992 GDP per capita to define the set of low-income countries. GDP data is drawn from the World Banks' World Development Indicators. See Appendix for the list of countries classified as low-income in our study.
} 
A number of features of these firm importing patterns stand out in the table. First, the share of firm imports coming from China has increased over time, and the smaller non-multinational firms rely more on China than do larger firms. Multinationals sourced 4 percent of their imports from China in 1997, and this share rose to 13 percent by 2012. Among arm's length traders, the share of imports coming from China doubled from 12 percent in 1997 to 24 percent in 2012. Interestingly, when we add China's share to the share for other low-income exporting countries, table 6 shows that the combined share of 19 percent for multinational firms is far less than the 37 percent for arm's length traders. Multinationals rely to a greater extent on the NAFTA partners, Canada and Mexico, than do firms without foreign affiliate trade. Arm's length importers received a combined 15 percent of their imports from these partners, far less than the 29 percent received by multinationals, many of which have affiliates in these countries. The share of imports coming from the European Union has declined over time for the two groups.

As seen by the information in Table 7, importing behavior by arm's length importing firms is quite heterogeneous across industries. Table 7 provides the value of imports from low-income countries, as a share of sales, by importing industry and year, for arm's length importers only. First, note that the value of imports from low-income countries has increased for most, but not all, industries over time. For some industries, such as textile products, the share rises dramatically while for other industries, such as beverages and tobacco, the share changes very little. Secondly, we see that imports from low-income countries are large relative to industry sales for only a subset of industries. Not surprisingly, the most labor intensive industries show the largest values: textile products, apparel, and leather all import bundles from low-income countries that exceed 8 percent of sales. Table 7 also shows that imports from low-income countries have risen dramatically over time for the computer and electronics industry, but that imports for non-multinationals in this 
sector were valued only at about 3.5 percent of sales revenue in 2012. Other noteworthy increases include those for electrical equipment and for printing and related activities, both of whose import bundle from low-income countries as a share of sales doubled between 1997 and 2012, and furniture and primary metal, both of whose low-income country import bundle quadrupled to 8.8 and 8.4 percent of sales revenue, respectively.

These imports may include final goods that firms import to resell under their brand names. In an attempt to isolate only goods that are used as inputs to the production process, we calculate the share of intermediate imports coming from low-income countries. To define which goods are intermediates in each firm's imported bundle, we include only imports identified as intermediate goods by the United Nation Statistics Division’s Broad Economic Categories (BEC) scheme. Table 8 shows the value of intermediate imports from low-income countries as a share of sales by importing industry for each year, only for those firms that engage only in arm's length importing. The table's contents are interesting for several reasons. First, when we consider only goods labeled intermediates by the BEC, low-income-country import shares of sales for the labor intensive industries -- textile products, apparel, and leather -- are quite low. Secondly, consistent with lowincome Asia’s move into global value chains, we see relatively large increases over the 15-year period for computer and electronic equipment, electrical equipment, transportation equipment, and furniture. We note, however, that intermediate imports from low-income countries do not exceed 3 percent of sales in any sector.

In addition to intermediate goods imported by U.S. manufacturers, American production may be replaced by final goods imported by wholesale and retail trading companies and sold directly on the US market. In Table 9, we present the value of total imports as a share of domestic absorption. Here, we do not use the firm-level data, using instead the total value of US imports in 
each industry. On average, imports have filled a larger share of domestic consumption across manufacturing industries, rising from about 7.4 percent in 1997 to almost 21 percent by 2012. However, this growth is not smooth across sectors and for some sectors there is little growth in the import share. Some sectors have experienced spectacular growth in import penetration, notably apparel and leather products, with import shares exceeding 75 percent of domestic absorption by 2007. Imported shares of computer and electronic equipment and textile products exceed 50 percent, consistent with media reports about rising import penetration in these sectors. In contrast, import penetration remains low in food, beverages and tobacco, and metal production.

The dramatic heterogeneity among manufacturing industries in sourcing behavior, documented in Tables 6-9, provides fertile ground for exploring how American domestic manufacturing firms adjusted domestic employment levels while engaging in offshoring, on one hand, and final-goods competition, on the other. We now turn to a description of the econometric model we will use to investigate these relationships.

\section{Model Specification and Variable Descriptions}

The firms in our analysis trade only at arm's length with foreign suppliers and can adjust employment in response to foreign competition only through changes at US locations. We limit our analysis to firms that survive over a 5-year observation period, so that we can observe both changes in employment and changes in firm importing behavior. This restriction, however, implies that the changes we observe do not capture employment losses at firms that exit during our observational period or employment gains at firms that enter.

\subsection{Empirical Specification}

We estimate the following type of regression to document contemporaneous changes in import patterns and a set of firm-level outcomes of interest: 


$$
\Delta \log Y_{i}=\alpha+\beta_{1} \Delta O F F_{i t}^{c}+\beta_{2} \Delta P E N_{j t}^{c}+\beta_{3} X_{i t}+\delta_{t}+\varepsilon_{i t},
$$

where $i$ indexes firms, $j$ industry and $t$ time. The dependent variable is the five-year change in $Y$, $\Delta \log Y_{i}=\log Y_{i, t+5}-\log Y_{i, t}$, where $Y$ is, alternatively, total employment, manufacturing employment, non-production employment, production employment, production to non-production wage bill ratio, and the production worker wage rate. $\triangle O F F_{i t}^{c}$ is the five-year change in offshoring from a country group, $c$, measured using firm-level import transactions records. $P E N_{j t}^{c}$ is an industry level measure of import penetration as in Bernard et al. (2006), constructed at the same three-digit NAICS level as the firm. $X_{i t}$ includes a set of time-varying firm-level controls, measured at the start of the time interval. The controls include firm age, total factor productivity, and start-of-period values of $Y$. For example, for the interval between 2002 and 1997, $X_{i t}$ is measured as of 1997, and so on. We also include a dummy for each time interval, $\delta_{t}$. Since we estimate a stacked first-difference model for three time periods - 1997-2002, 2002-2007, and 20072012 - firm fixed effects are swept out. $\varepsilon_{i t}$ is an idiosyncratic error term. We estimate weighted regressions where total firm employment in the initial year is used as the weight and standard errors are clustered at the three-digit industry level.

The key variables of interest in our analysis are $O F F_{i t}^{c}$ and $P E N_{j t}^{c}$, which may both suffer from endogeneity. Although $P E N_{j t}^{c}$ can be reasonably considered as given when the firm is solving its optimization process, there may be omitted variables that influence both the import penetration measures and outcomes of interest. Import shares and their evolution over time may be correlated with industry-level unobservable factors, such as technological change or local demand shocks, that also impact the firm-level outcomes of employment and wages. Firm-level measures of offshoring, $O F F_{i t}^{c}$, may suffer from endogeneity due to simultaneity bias as opposed to omitted 
variables bias. This is because a firm's decision to engage in offshore outsourcing is likely to simultaneously influence and be influenced by the outcomes of interest.

While we recognize these concerns, finding instrumental variables for firm-level imports is difficult. Following Mion and Zhu (2013), we used exogenous variation in exchange rates and tariffs as predictors for changes in $O F F_{i t}^{c}$ and $P E N_{j t}^{c}$. Movements in exchange rates and tariffs can be expected to be correlated with industry import shares and firm offshoring (instrument relevance), however, exchange rate and tariffs are driven by global macroeconomic factors that are unlikely to be correlated with omitted variables (instrument exogeneity). Unfortunately, the power of these instruments when used with US firm-level data was quite weak and in this paper we report the results of fixed effect regressions that provide correlations between changes in import bundles and changes in firm’s employment and wage levels.

\subsection{Variables of Interest}

Dependent variables. To study firm employment and wage inequality, we construct log measures of five-year changes in each a set of outcome variables. We measure employment changes as follows,

$$
\Delta \log \text { Employment }_{i}=\log \text { Employment }_{i, t+5}-\log \text { Employment }_{i, t} .
$$

We consider four alternative measures of employment. ${ }^{12}$ The first measure is total firm employment, which captures employment across all establishments belonging to a firm. Since multi-establishment firms may span several sectors of the economy, this measure includes employment in both manufacturing and non-manufacturing establishments of the firm. The second measure is total manufacturing employment, which narrows our focus to employment across all manufacturing establishments only of the firm. The third type of employment we explore is total

\footnotetext{
12 Total employment is sourced from the LBD while all other employment numbers are drawn from the CMF.
} 
production employment, which measures the total number of production workers employed across all manufacturing establishments of the firm. The fourth and final measure of employment we consider is total non-production employment, which captures the total number of non-production workers employed across all manufacturing establishments of the firm. This measure is constructed as total manufacturing employment less total production employment.

We also investigate two measures of income inequality. The change in the wage bill ratio between non-production and production workers is measured as follows:

$$
\Delta \log \left(\frac{N P \text { Wagebill }}{P \text { Wagebill }}\right)_{i}=\log \left(\frac{N P \text { Wagebill }}{P \text { Wagebill }}\right)_{i, t+5}-\log \left(\frac{N P \text { Wagebill }}{P \text { Wagebill }}\right)_{i, t} .
$$

The wage bill ratio is measured as the share of wage bill of non-production workers to wage bill of production workers. We use this measure because our data sources do not allow calculation of the average non-production worker wage at the firm level. However, the CMF does provide information on the total annual hours worked for production workers and we use these firm-level data to calculate the wage rate of production workers at each firm. We calculate the change in the wage rate of production workers measured as follows:

$$
\Delta \log \left(\frac{P \text { Wagebill }}{\text { Annual P Hours }}\right)_{i}=\log \left(\frac{P \text { Wagebill }}{\text { Annual P Hours }}\right)_{i, t+5}-\log \left(\frac{P \text { Wagebill }}{\text { Annual P Hours }}\right)_{i, t} .
$$

Independent variables. We have three main explanatory variables of interest - two measures of firm-level offshoring and one measure of industry-wide import competition constructed at the three digit NAICS level. We construct the offshoring measures using firm-level imports. Firm-level import transactions offer several important advantages when trying to measure offshore outsourcing. According to Hummels, Munch, and Xiang (2016), a measure of offshoring should capture (i) intermediate inputs not final goods, (ii) imported and not domestically produced inputs, and (iii) inputs that could have been produced internally within the firm. Firm import transactions are mainly composed of inputs and, thus, omit many of the final goods included in 
import penetration measures based on US economy-wide import data. Clearly, firm import transactions meet condition (ii) as they record only goods not produced domestically. Finally, firm import transactions capture the value of many intermediates that could have been produced internally by the firm, although the extent to which they substitute for domestic employment explicitly is not known. A drawback of the firm import transactions is that they do not capture imported intermediates sold by wholesalers to firms that do not themselves engage directly in trade. We do not know how large a phenomenon offshore outsourcing through trading intermediaries is.

We begin by focusing directly on firm-level imports. Using import transaction records matched to US domestic firms, we create a measure of offshoring based on firm's direct imports, differentiated by source country group, and weighted by total value of shipments:

(a) $O F F_{i t}^{c}=\frac{\text { Imports }_{i t}^{c}}{\text { Sales }_{i t}}$,

where $i$ indexes firm, $c$ country group and $t$ time. We consider two country groups - low-income and the rest of the world. The numerator is the sum of all firm-level imports from one of the two country groups in a given year. We divide this by firm-level total value of shipments. The resulting variable - $O F F_{-} L I_{i t}$ and $O F F_{-} O T H_{i t}$ - capture firm-level imports from low-income and other countries, respectively. Since we consider direct imports by manufacturing firms and exclude a firm's trade in resource intensive products, these imports are expected to be comprised mainly of inputs to production that could have been produced internally by the firm. ${ }^{13}$

To reduce further the risk of including in our offshoring measure imports that do not substitute for domestic production, we also create a narrower measure of offshoring by limiting our calculations to firm imports of intermediate goods. In order to distinguish between imports of

${ }^{13}$ This approach is similar to that used by Hummels, Jørgensen, Munch, and Xiang (2014). 
final and intermediate goods, we use the United Nation's classification by broad economic categories. We use the 2007 correlations between the BEC categories and six-digit HS codes to isolate import transactions that are intermediates. ${ }^{14}$ For each firm we then calculate:

$$
\text { (b) } O F F_{-} I N T_{i t}=\frac{\text { Intermediate Imports }}{\text { it }} \text {. }
$$

We derive two measures - OFF_INT_LI $I_{i t}$ and $O F F_{-} I N T_{-} O T H_{i t}$ - firm-level intermediate goods imports from low-income and other countries, respectively.

Figure 1 illustrates the trends in both measures of offshoring, relative to the base year 1997. As seen in Panel A, our broad measure of offshoring, which includes all goods imported directly by manufacturing firms engaged in arm's length trade, increases steadily over the 15-year period, although it only really takes off after 2002. We see more rapid growth in imports from low-income countries, with the value of such imports as a share of sales more than tripling over the interval. In contrast, imports from other countries increase much more slowly, rising by only 50 percent by 2012. Panel B shows similar trends, but for the narrow measure of offshoring that includes only imports categorized as intermediate good by the BEC classification system. Again, offshoring doesn't really take off until after 2002 and the rise for imports from low-income countries far outpaces that for imports from other sources.

To distinguish offshoring from import competition on domestic final-goods markets, we also calculate industry-wide import penetration measures following Bernard et al. (2006):

$$
\text { PEN }_{j t}^{c}=\frac{\text { Imports }_{j t}^{c}}{\text { Imports }_{j t}+\text { Sales }_{j t}-\text { Exports }_{j t}} .
$$

We create two measures - $P E N_{-} L I_{j t}$ and $P E N_{-} O T H_{j t}$ - of industry-wide import penetration from low-income and other countries, respectively. To calculate industry level imports, we concord 10-

\footnotetext{
${ }^{14}$ See http://unstats.un.org/unsd/trade/BEC\%20Classification.htm.
} 
digit HS codes to six-digit NAICS codes using the HS-NAICS bridge developed by Pierce and Schott (2010). The bridge file is updated through 2009. ${ }^{15}$ We use the 2009 concordance to concord HS to NAICS codes in $2011 .^{16}$

Figure 2 illustrates the trends in overall import penetration, relative to the base year 1997. Again, we see only a small increase in either index by 2002. Penetration from low-income countries soars between 2002 and 2007, with the index increasing by 800 percent, before falling back after the onset of the Great Recession in 2008. In contrast, import penetration from other countries barely changes over the interval, with the index almost fully returned to unity by 2012.

Control variables. To control for other determinants of employment dynamics, we include firm age and the initial level of the variable of interest, all sourced from the LBD. For multi-plant firms, we consider the age of the oldest establishment. We also control for total factor productivity (TFP). Using data from the CMF, TFP is calculated for each establishment as the residual from a three-factor production function where factor elasticities are derived from industry-level cost shares for each input (Foster, Grim, and Haltiwanger, 2013). As discussed earlier, firms may have establishments operating in different sectors as well as different industries within the manufacturing sector. To create a firm-level TFP measure for our analysis, we first de-mean the establishment-level TFP measure so that it is comparable across industries. Then we create establishment weights based on each unit's contribution to the share of total firm shipments and then multiply the TFP measures with these establishment weights. Finally, we create a weighted TFP measure aggregated at the firm level. All control variables are measured as of the initial year. For example, for the change between 1997 and 2002, the initial value is 1997, and so forth.

\footnotetext{
${ }^{15}$ Accessed at http://faculty.som.yale.edu/peterschott/sub_international.htm.

${ }^{16}$ We were unable to link approximately three percent of total observations, accounting for about $1.5 \%$ of trade value, to a NAICS code in 2011.
} 


\section{Estimation Results}

\subsection{Impacts of Firm-level Offshoring on Arm's Length Importers}

We first estimate equation (1) excluding the industry-wide import penetration measures to assess the impact of offshoring only. Table 10 reports the relationship between offshoring and firm employment growth, growth in the ratio of non-production to production workers' wage bill, growth in production workers' wage rate. Again, our sample includes only surviving firms that have no trade with related parties and, thus, reflects outcomes at US manufacturers that only trade at arm's length. Because we also include a dummy for each time period in our regression estimation, the employment changes we discuss below can be interpreted as deviations from the period average.

From Table 10, we see that both employment and wage growth are negatively related to changes in firm-level offshoring from low-income countries, but significantly so only for manufacturing employment and average production worker wage rates. A one percentage point change in firm-level imports from low-income countries (e.g. from an OFF_LI value of $1 \%$ to a value of $2 \%$ ) is associated with a $0.0087 \%$ decline in manufacturing employment and a $0.007 \%$ change in the production worker wage rate. The estimated coefficients in column (2) indicate that a one standard deviation growth in OFF_LI is associated with a decline in manufacturing employment growth of 0.039 standard deviations. Growth in imports from other countries is associated with a decline in total employment growth of 0.004 standard deviations. ${ }^{17}$ Looking between columns (3) and (4), we can see that the total decline in manufacturing employment growth associated with growth in OFF_LI is led by a slightly larger decline in production employment. Under column (3), a one standard deviation increase in OFF_LI growth is associated

\footnotetext{
${ }^{17}$ Beta coefficients are estimated using the "beta” option in Stata’s “regress” command. For details on Stata's routine to estimate beta coefficients see http://www.stata.com/manuals13/rregress.pdf.
} 
with a 0.033 (0.027) standard deviation decline in production (non-production) manufacturing employment growth.

In Table 11, we consider a more narrowly defined measure of offshoring, firm-level imports of intermediate goods as a share of firm sales. We find that offshoring of intermediate goods from low-income countries is negatively and significantly associated with total and manufacturing employment, as well as both non-production and production employment individually. Looking at column (2), a one percentage point increase in the intermediates offshoring measure is associated with a total manufacturing employment decline of $0.15 \%$, a much larger associated change in employment than suggested by table 10 for general firm-level imports. Given that magnitudes and changes in the narrow measure differ from those for the broad offshoring measure, we again report standardized beta coefficients. A one standard deviation increase in OFF_INT_LI growth is associated with a 0.074 standard deviation decline in total employment growth, and a larger 0.22 standard deviation decline in manufacturing employment. The decline in total manufacturing employment is led by a decline in production employment, comparing coefficients in columns (3) and (4). A one percentage point increase in offshoring of intermediate goods is associated with a $0.14 \%$ decline in non-production employment compared to a $0.17 \%$ decline in production employment and an overall decline in manufacturing employment of $0.15 \%$. Referring to column (6), we also see that offshoring of intermediate goods from lowincome countries is negatively and significantly associated with the average production wage rate.

In contrast, by looking across the second row of coefficients, we see that purchases of intermediate goods from countries other than those in the low-income group are positively and significantly associated with changes in all measures of employment and with production wage rates. The increase in manufacturing employment due to increases in OFF_INT_OTH is led by 
increases in production employment. The estimated coefficient suggests that a one percentage point increase in the narrow index for non-low-income offshoring is associated with a $0.03 \%$ increase in production employment.

Comparing the relative impacts of broad offshoring versus narrow offshoring of intermediate goods from low income countries, our results suggest that intermediate goods offshoring is associated with larger declines in employment and the production wage rate than is the full bundle of firm-level imports. Correlations between narrowly defined offshoring and employment changes (provided by Table 11) are significantly larger than the correlations between broadly defined offshoring and employment changes (provided in Table 10). We also find evidence of differences in how imports from low-income countries are used by the firm, in comparison to imports from higher income countries. While broad offshoring from other countries is negatively correlated with overall employment growth, offshoring of intermediates from other countries is significantly and positively correlated with both total and manufacturing employment growth. These overall patterns are consistent with the idea that imported intermediate inputs from low income countries may be substitutes for domestic labor while imported intermediate inputs from higher income countries may be complements to domestic labor. It is also possible that these results reflect the influence of unobserved shocks to firm level demand, which raise both employment and intermediate imports from higher income countries. However, they affirm the need for further research that differentiates offshored inputs by source country. ${ }^{18}$

\footnotetext{
${ }^{18}$ These results are consistent with results for earlier time periods. Lovely and Richardson (1996) explore differences in the labor market impact of imports differentiated by country income level using worker micro data from 1981-1992. They measure U.S. trade flows with three groups of trading partners -- industrial countries, newly industrial countries, and primary producers -- and estimate the correlation of these trade flows with several types of wage premiums, using conditioning methods that separate pure wage premiums from the return to education by industry. They find that greater U.S. trade with newly industrializing countries is associated with increased rewards to skill and reduced rewards to pure labor, consistent with heightened wage inequality and distributional conflict. The opposite is usually true of greater trade with traditional industrial countries.
} 
In both Tables 10 and 11, firm age is negatively and statistically significantly correlated with changes in employment and the wage bill ratio, but positively correlated with changes in the production wage rate. This relationship is reversed with TFP, indicating that, all else equal, employment in all categories grew at more productive firms. Across all regressions, initial $Y$ values are negatively correlated with subsequent changes in $Y$.

\subsection{Impacts of Offshoring and Industry-wide Import Competition on Arm's Length}

\section{Importers}

In Table 12 we use equation (1) to estimate the relative impacts of changes in firm-level and industry-level import penetration on growth in employment, wage-bill ratio, and production wage rate. Controlling for changes in industry-wide import competition, we continue to find that changes in firm-level offshoring from low-income countries are negatively and significantly related to manufacturing employment changes and changes in the average production workers’ wage. Interestingly, comparing results in Table 10 with those in Table 12, we see that coefficient values for changes in firm-level imports are not affected by inclusion of controls for industry-wide import penetration.

Results in Table 12 also indicate that changes in employment and the average production wage rate are negatively related to industry-wide import penetration from low-income countries, a finding similar to Bernard et al. (2006) and Mion and Zhu (2013). A one percentage point increase in import penetration from low income countries is significantly associated only with changes in manufacturing production employment: the coefficient estimates suggests that a one percentage point increase in the import penetration measure is associated with a reduction in production employment of $0.69 \%$ and a $0.1 \%$ increase in the wage bill ratio. A one standard deviation increase in PEN_LI is associated with a decrease in manufacturing production 
employment growth of 0.056 standard deviation while a one standard deviation increase in OFF_LI is associated with a decrease in manufacturing employment growth of 0.032 . These results suggest that deepening of industry-wide import competition is associated with larger employment declines that are similar in magnitude to that of narrow firm offshoring.

Comparing results in Table 11 with those in Table 13, we again see that coefficient values for changes in firm-level imports, this time using the narrow offshoring measures, are not affected by inclusion of controls for industry-wide import penetration. Moreover, the correlations between import penetration and employment we found when using a broad measure of offshoring are preserved when we substitute the narrow measure of offshoring. As seen in Table 13, a one percentage point increase in import penetration from low-income countries is associated with $0.69 \%$ decline in production employment and a $1.17 \%$ increase in the wage bill ratio, almost the same magnitudes we found controlling for broad offshoring. Finally, we continue to find a positive and significant correlation between the production wage rate and changes in offshoring of intermediate goods from non-low-income countries.

\subsection{Impacts of Industry-Wide Import Competition on Non-Traders}

Thus far we have focused on arm's length importers - firms that import only or engage in both exporting and importing but do so only with unrelated parties. However, non-trading firms may also be impacted by import penetration of final-goods markets. In Table 14, we estimate equation (1) using data from non-traders only, replacing firm-level measure of offshoring with industry-wide measures of import competition from both low-income $\left(P E N_{-} L I_{j t}\right)$ and other countries $\left(P E N \_O T H_{j t}\right)$. We find no statistically significant relationship between changes in import competition (PEN_LI and PEN_OTH) and changes in employment, the wage bill ratio, and average production wage rate at non-trading firms. The only exception is that a change in 
PEN_OTH is statistically significantly and positively correlated with changes in the average production wage rate, suggestive of non-traders using imported inputs from higher income countries as complements to domestic production labor.

Non-trading firms in our sample are very small, with about 21 workers on average, compared to the arm's length traders. These small firms may be niche suppliers to larger firms such that non-trading firms in our sample were insulated from direct industry-wide import competition. Coupled with our research design, where we focus on firms that survive over multiple census periods, it is possible that some non-traders exit the market completely such that our sample of non-traders captures only those firms that do not exhibit significant changes in employment in response to increases in industry-wide import competition. We note here that this discussion is purely speculative and establishing these claims firmly is beyond the scope of the current paper. However, the results suggest that rigorously examining the impact of import competition on firm entry and exit is a fruitful avenue for future research.

\subsection{Economic Magnitudes}

To further assess the magnitude of the associations suggested by our results, we calculate the change in employment at surviving arm's length trading firms that is implied by the coefficient estimates for several specific industries. We begin with a consideration of the industry that accounts for the largest share (11\%) of total manufacturing employment in 2002, transportation equipment manufacturing. Between 2002 and 2007, a period highlighted by rapid growth in imports from China, our broad measure of offshoring, firm-level imports as a share of sales, increased by 0.6 percentage point for transportation equipment. ${ }^{19}$ Using the regression coefficient for OFF_LI from Table 12, we calculate that this slight increase in offshoring occurred

\footnotetext{
${ }^{19}$ This is the average change in the offshoring measure for transportation equipment manufacturing when we weight firms by their share of industry employment. The unweighted change in offshoring is 1.1 percentage points.
} 
contemporaneously with a reduction in manufacturing employment at surviving firms in this industry of $0.05 \%$ - in other words, by a very small amount. Turning to the impact of productmarket competition, imports from low-income countries as a share of domestic absorption increased by 2.35 percentage points between 2002 and 2007 for the transport industry, as seen in Table 9. Using the coefficient estimates in Table 12, this increase in import penetration was associated with a reduction in manufacturing employment in transportation equipment by $1.2 \%$ over the period among surviving firms. This loss can be viewed in comparison to the $4.6 \%$ increase in employment experienced over the same period at surviving firms in the industry.

We next consider an industry that is comparatively labor intensive: leather and allied product manufacturing. The leather industry employed only $0.33 \%$ of total US manufacturing workers in 2002. Between 2002 and 2005, firm-level imports as a share of sales increased by 4 percentage points for the industry. Using the regression coefficient for OFF_LI from Table 12, we calculate that this increase in offshoring was matched by a reduction in leather manufacturing employment at surviving firms in this industry of $0.034 \%$ - a small share of the $3.1 \%$ decline in the leather employment at surviving firms. Turning to the impact of product-market competition, our measure of import penetration, imports from low-income countries as a share of domestic absorption, increased by 10.5 percentage points for leather between 2002 and 2007, as seen in Table 9. Using the coefficient estimates in Table 12, this increase in import penetration was matched by reduced employment in leather manufacturing by $5.4 \%$ over the period among surviving firms. The industry's actual job loss was smaller than this, suggesting that firms were able to strategically adjust to increased competition.

The evidence from these two industries illustrate several of the main trends we find in the data. First, while offshoring to low-income countries is associated with employment losses at 
surviving firms, the estimated employment losses are quite small. Secondly, the losses associated with import competition from low-income countries are substantially larger. Finally, the magnitude of employment losses correlated with both offshoring and import competition varies widely across industries because of substantial differences in import penetration.

\section{Conclusions}

In this paper we explore basic patterns in the levels and shares of manufacturing employment at firms that have at least one manufacturing establishment for 1997, 2002, 2007 and 2012. We further classify firms into five mutually exclusive categories based on their degree of global engagement - multinationals, importers only, importer and exporter, exporters only, nontraders. We find that multinational firms account for the lion's share of manufacturing employment as well as the largest declines in manufacturing employment between 1997 and 2012 . Multinationals also tend to be significantly larger than the other firm types and tend to import less from China and more from NAFTA partner countries than do firms that import at arm's length.

We focus attention on arm's length importers to better understand the dynamics of offshoring and employment at firms whose trade patterns are not influenced by foreign affiliates. We find that offshoring from low-income countries by this group of firms is associated with manufacturing employment declines. Greater offshoring correlates with larger declines in both production and nonproduction employment and in the average production employee wage. We find no significant correlation between offshoring to other (non-low-income) countries and manufacturing employment, but surprisingly find a positive correlation with the average production employee wage. Given the negative association, however, our estimated magnitudes

are small, even when we consider a narrow measure of offshoring that includes only imports of intermediate inputs. 
In contrast to our results for offshoring, we estimate economically meaningful and robust correlations between import penetration from low-income countries and employment. Greater product market competition from low-income countries is associated with significant declines in the employment of manufacturing production workers and increases in the non-production/ production wage bill ratio. We find no significant relationship between import competition from low-income countries and the average production workers' wage rate. Notably, import penetration is associated with employment declines at arm's length traders but not at firms that do not trade.

Overall, these results suggest that trade with low-income countries has been matched by contemporaneous declines in manufacturing employment and downward pressure on production worker wage rates. The magnitude of these effects, however, is small when trade takes place at the firm level. While the evidence is consistent with some substitution of offshore outsourcing for domestic production, the implied magnitude of the association is not large. In contrast, we find evidence consistent with a stronger relationship between production employment declines and import penetration. While imports from middle and high-income countries are not significantly correlated with employment changes at U.S. firms, imports from low-income countries are correlated with a loss in production employment. The likely effects of these competitive pressures, however, are economically large only for those industries where import penetration rose rapidly over the 15-year period we study. These highly exposed industries include the familiar laborintensive industries - textiles, apparel, and leather - and also the highly fragmented sectors computer and electronic equipment manufacturing and electrical equipment manufacturing. Suggested employment and wage effects for other industries are quite small, both from offshoring and from import penetration. 


\section{Acknowledgments}

This paper was prepared for the conference "Trade, Growth and Economic Inequality in the AsiaPacific Region", organized by Theresa Greaney, Baybars Karacaovali and Kozo Kiyota and hosted by Keio University in May 2016. The authors gratefully acknowledge conference project financial support from The Japan Foundation Center for Global Partnership; and from co-sponsors Keio Economic Observatory and MEXT-supported Program for the Strategic Research Foundation at Private Universities; and the University of Hawai 'i Center for Japanese Studies, College of Social Sciences, and Economics Department. We also thank discussant Hong $\mathrm{Ma}$, the conference organizers, and other conference participants for their valuable comments on our paper. The authors also gratefully acknowledge comments from Nikolas Zolas, Shawn Klimek and seminar participants at the Honolulu Pre-conference in January 2016, Spring 2016 Midwest International Economics Meetings, and 2016 Center for Economic Studies Brown Bag Seminar Series at the U.S. Census Bureau. We thank Billy Wisniewski for timely disclosure review and James Boohaker for excellent research assistance. 


\section{References}

Amiti, M. and Wei, S. 2009. Does Service Offshoring Lead to Job Loss? Evidence from the United States. In M. Reinsdorf \& M. J. Slaughter (eds.), International Trade in Services and Intangibles in the Age of Globalization, the University of Chicago Press, Chicago, pp. 227-243.

Acemoglu, Daron, David Autor, David Dorn, Gordon H. Hanson, and Brendan Price. 2016. Import Competition and the Great U.S. Employment Sag of the 2000s. Journal of Labor Economics 34 (S1): S141-S198.

Autor, D. H., Dorn, D., and Hanson, G. H. 2013. The China Syndrome: Local Labor Market Effects of Import Competition in the United States. American Economic Review 103(6): 2121-2168.

Bailey, M.N. and Bosworth, B.P. 2014. US Manufacturing: Understanding Its Past and Its Potential Future. Journal of Economic Perspectives 28(1): 3-26.

Bernard, A., Jensen, J.B., Schott, P. 2006. Survival of the Best Fit: Exposure to Low-Wage Countries and the (Uneven) Growth of U.S. Manufacturing Plants. Journal of International Economics 68: 219-237.

Bernard, A., Jensen, J.B., Redding, S. and Schott, P. 2015. Global Firms. Mimeo.

Biscourp, P. and Kramarz, F. 2007. Employment, Skill Structure, and International Trade: Firm Level Evidence for France. Journal of International Economics 72: 22-51.

Boehm, C., Flaaen, A., and Pandalai-Nayar, N. 2015. Multinationals, Offshoring, and the Decline of U.S. Manufacturing. Mimeo.

Cooke, A., Kemeny, T., Rigby, D. 2014. Cheap Imports and the Loss of U.S. Manufacturing Jobs, The World Economy 38(10), 1555-1573.

Edwards, L. and Lawrence, R.Z. 2013. Rising Tide: Is Growth in Emerging Economies Good for the United States? Washington, DC: Peterson Institute for International Economics.

Feenstra, R. C., Hanson, G. H. 1999. The Impact of Outsourcing and High-technology Capital on Wages: Estimates for the United States, 1979-1990. Quarterly Journal of Economics, 114, 907940.

Foster, L., Grim, C. and Haltiwanger, J. 2014. Reallocation in the Great Recession: Cleansing or Not? NBER Working Paper 20427.

Harrison, A. and McMillan, M. 2011. Offshoring Jobs? Multinationals and US Manufacturing Employment. Review of Economics and Statistics 93(2): 857-875.

Hsieh, C. T., Woo, K. T. 2005. The Impact of Outsourcing to China on Hong Kong's Labor Market. American Economic Review, 95(5), 1673-1687. 
Hummels, D., Ishii, J., Yi, K-M. 2001. The Nature and Growth of Vertical Specialization in World Trade. Journal of International Economics 54(1): 75-96.

Hummels, D., Munch, J. R. and Xiang, C. 2016. Offshoring and Labor Markets. NBER Working Paper 22041.

Hummels, D., Jørgensen, R., Munch, J. R. and Xiang, C. 2014. The Wage Effects of Offshoring: Evidence from Danish Matched Worker-Firm Data. American Economic Review 104(6): 15971629.

Jarmin, R. S. and Miranda, J. 2002. The Longitudinal Business Database. Working Paper 02-17, Center for Economic Studies, U.S. Census Bureau.

Lovely, M.E. and Richardson, J.D. 2000. Trade Flows and Wage Premiums: Does Who or What Matter? in Robert C. Feenstra, (ed.), The Impact of International Trade on Wages, the University of Chicago Press, Chicago, pp. 309-343.

Mion, G. and Zhu, L. 2013. Import Competition from and Offshoring to China: A Curse or Blessing for Firms? Journal of International Economics 89: 202-215.

Pierce, J. and Schott, P. 2012. Concording U.S. Harmonized System Codes and SIC/NAICS Product Classes and Industries. Journal of Economic and Social Measurement 37(1-2): 61-96.

Pierce, J. and Schott, P. 2016. The Surprisingly Swift Decline of U.S. Manufacturing Employment. American Economic Review 106(7): 1632-1662.

Scott, R.E. 2015. The Manufacturing Footprint and the Importance of U.S. Manufacturing Jobs. EPI Briefing Paper 388, Economic Policy Institute, Washington, D.C. 
Table 1. Manufacturing Employment, By Trading Status and Year

\begin{tabular}{|c|c|c|c|c|c|c|}
\hline \multirow[b]{2}{*}{ Trading Status } & \multicolumn{2}{|c|}{$\begin{array}{l}\text { Manufacturing } \\
\text { Employment } \\
\text { (in millions) }\end{array}$} & \multicolumn{4}{|c|}{ Change in Manufacturing Employment } \\
\hline & 1997 & 2012 & $\begin{array}{c}1997- \\
2002\end{array}$ & $\begin{array}{c}2002- \\
2007\end{array}$ & $\begin{array}{l}2007- \\
2012\end{array}$ & $\begin{array}{l}1997- \\
2012\end{array}$ \\
\hline All Firms & 17.02 & 10.80 & -0.17 & -0.09 & -0.16 & -0.37 \\
\hline Multinational & 8.66 & 5.47 & -0.11 & -0.14 & -0.17 & -0.37 \\
\hline Import Only & 0.29 & 0.18 & -0.18 & -0.07 & -0.19 & -0.38 \\
\hline Import and Export & 3.35 & 2.34 & -0.16 & -0.02 & -0.15 & -0.30 \\
\hline Export Only & 2.16 & 1.33 & -0.21 & -0.04 & -0.19 & -0.38 \\
\hline Non-traders & 2.57 & 1.48 & -0.33 & -0.05 & -0.10 & -0.42 \\
\hline
\end{tabular}

Table 2. Total Employment at Firms that Manufacture, By Trading Status and Year

\begin{tabular}{lcccccc}
\hline & \multicolumn{2}{c}{$\begin{array}{c}\text { Total Employment } \\
\text { (in millions) }\end{array}$} & \multicolumn{5}{c}{ Change in Total Employment } \\
\cline { 4 - 7 } Trading Status & $\mathbf{1 9 9 7}$ & $\mathbf{2 0 1 2}$ & $\mathbf{1 9 9 7 -}$ & $\mathbf{2 0 0 2 -}$ & $\mathbf{2 0 0 7 -}$ & $\mathbf{1 9 9 7 -}$ \\
& & & $\mathbf{2 0 0 2}$ & $\mathbf{2 0 0 7}$ & $\mathbf{2 0 1 2}$ & $\mathbf{2 0 1 2}$ \\
\hline All Firms & 30.57 & 22.35 & -0.09 & -0.07 & -0.14 & -0.27 \\
Multinational & 17.69 & 13.95 & 0.002 & -0.07 & -0.16 & -0.21 \\
Import Only & 0.50 & 0.38 & -0.20 & 0.09 & -0.14 & -0.25 \\
Import and Export & 5.97 & 4.01 & -0.17 & -0.10 & -0.10 & -0.33 \\
Export Only & 3.17 & 1.85 & -0.24 & -0.07 & -0.18 & -0.42 \\
Non-traders & 3.24 & 2.13 & -0.26 & -0.05 & -0.07 & -0.34 \\
\hline $\begin{array}{l}\text { Notes: Our sample only includes firms that have at least one manufacturing establishment. Columns 4-7 } \\
\text { display the percentage change in total employment in each five-year interval. }\end{array}$
\end{tabular}


Table 3. Share of Firms, By Trading Status and Year

\begin{tabular}{lcccc}
\hline Trading Status & $\mathbf{1 9 9 7}$ & $\mathbf{2 0 0 2}$ & $\mathbf{2 0 0 7}$ & $\mathbf{2 0 1 2}$ \\
\hline Multinational & 0.03 & 0.05 & 0.04 & 0.04 \\
Import Only & 0.03 & 0.03 & 0.03 & 0.03 \\
Import and Export & 0.12 & 0.16 & 0.16 & 0.16 \\
Export Only & 0.19 & 0.22 & 0.22 & 0.21 \\
Non-traders & 0.62 & 0.54 & 0.54 & 0.55 \\
\hline
\end{tabular}

Notes: This table displays the percentage share of firms by type in a given year. Our sample only includes firms that have at least one manufacturing establishment.

Table 4. Share of Manufacturing Employment, By Trading Status and Year

\begin{tabular}{lcccc}
\hline Trading Status & $\mathbf{1 9 9 7}$ & $\mathbf{2 0 0 2}$ & $\mathbf{2 0 0 7}$ & $\mathbf{2 0 1 2}$ \\
\hline Multinational & 0.51 & 0.54 & 0.51 & 0.51 \\
Import Only & 0.02 & 0.02 & 0.02 & 0.02 \\
Import and Export & 0.20 & 0.20 & 0.21 & 0.22 \\
Export Only & 0.13 & 0.12 & 0.13 & 0.12 \\
Non-traders & 0.15 & 0.12 & 0.13 & 0.13 \\
\hline
\end{tabular}

Notes: This table displays the share of manufacturing employment by type in a given year. Our sample only includes firms that have at least one manufacturing establishment.

Table 5. Average Firm Characteristics, By Trading Status

\begin{tabular}{lcccc}
\hline Type & $\begin{array}{c}\text { Manufacturing } \\
\text { Employment }\end{array}$ & Age & $\begin{array}{c}\text { Import Value } \\
\text { (in million USD) }\end{array}$ & $\begin{array}{c}\text { Multi-Unit } \\
\text { Status }\end{array}$ \\
\hline All Firms & 86.64 & 15.99 & 4.12 & $11 \%$ \\
Multinational & $1,086.52$ & 22.61 & 95.81 & $62 \%$ \\
Import Only & 45.95 & 14.63 & 0.33 & $10 \%$ \\
Import and Export & 120.30 & 19.41 & 0.99 & $22 \%$ \\
Export Only & 51.62 & 18.62 & NA & $10 \%$ \\
Non-traders & 20.55 & 13.73 & NA & $4 \%$ \\
\hline
\end{tabular}

Notes: This table displays the average manufacturing employment, age, import value and multiunit status by type over 1997, 2002, 2007 and 2012. Our sample only includes firms that have at least one manufacturing establishment. 
Table 6. Share of firm imports by source, trading status and year

\begin{tabular}{ccccccccc}
\hline \multicolumn{4}{c}{ Multinational } & & & \multicolumn{5}{c}{ Arm's Length } \\
$\mathbf{1 9 9 7}$ & $\mathbf{2 0 0 2}$ & $\mathbf{2 0 0 7}$ & $\mathbf{2 0 1 2}$ & Country Group & $\mathbf{1 9 9 7}$ & $\mathbf{2 0 0 2}$ & $\mathbf{2 0 0 7}$ & $\mathbf{2 0 1 2}$ \\
\hline 0.22 & 0.22 & 0.17 & 0.15 & Canada & 0.05 & 0.05 & 0.10 & 0.09 \\
0.12 & 0.13 & 0.13 & 0.14 & Mexico & 0.07 & 0.08 & 0.04 & 0.06 \\
0.04 & 0.08 & 0.12 & 0.13 & China & 0.12 & 0.20 & 0.26 & 0.24 \\
0.05 & 0.04 & 0.08 & 0.08 & Low Income (ex. China) & 0.10 & 0.09 & 0.11 & 0.13 \\
0.17 & 0.20 & 0.18 & 0.16 & European Union & 0.15 & 0.15 & 0.13 & 0.11 \\
0.39 & 0.33 & 0.34 & 0.34 & Rest of World & 0.50 & 0.42 & 0.36 & 0.36 \\
\hline Notes: This table displays the share of imports sourced from six country groups by multinational and arm's \\
length importers, respectively. Low-income group excludes China. Rest of World refers to all other countries.
\end{tabular}


Table 7. Firm imports from low-income countries as a share of sales (\%), by importing industry and year, arm's-length importers only

\begin{tabular}{lcccc}
\hline Industry & $\mathbf{1 9 9 7}$ & $\mathbf{2 0 0 2}$ & $\mathbf{2 0 0 7}$ & $\mathbf{2 0 1 2}$ \\
\hline Food & 0.459 & 0.358 & 0.909 & 0.595 \\
Beverage and Tobacco & 0.172 & 0.150 & 0.163 & 0.198 \\
Textile Mills & 1.789 & 2.227 & 3.754 & 4.990 \\
Textile Product Mills & 2.879 & 5.627 & 10.279 & 8.284 \\
Apparel & 7.810 & 8.098 & 12.519 & 9.275 \\
Leather & 9.432 & 10.600 & 10.825 & 11.624 \\
Wood & 0.466 & 1.104 & 2.176 & 1.960 \\
Paper & 0.356 & 0.427 & 0.659 & 0.903 \\
Printing and Related & 2.303 & 0.972 & 2.192 & 4.352 \\
Petroleum and Coal & 0.140 & 0.013 & 0.024 & 0.143 \\
Chemical & 0.823 & 1.190 & 1.013 & 1.800 \\
Plastics and Rubber & 1.077 & 0.586 & 2.283 & 2.099 \\
Nonmetallic Mineral & 0.381 & 1.116 & 1.542 & 1.464 \\
Primary Metal & 0.213 & 0.220 & 1.831 & 0.843 \\
Fabricated Metal & 0.427 & 0.869 & 1.522 & 2.323 \\
Machinery & 0.251 & 0.683 & 1.144 & 1.780 \\
Computer and Electronic & 1.202 & 1.944 & 1.664 & 3.411 \\
Electrical Equipment & 1.496 & 2.156 & 3.258 & 2.872 \\
Transportation Equipment & 0.358 & 0.576 & 1.203 & 1.563 \\
Furniture & 1.663 & 4.130 & 6.637 & 8.820 \\
Miscellaneous & 2.472 & 3.965 & 5.831 & 8.092 \\
\hline
\end{tabular}

Notes: This table displays industry averages of low-income country imports as a share of total sales by 3-digit NAICS categories. See text for a definition of arm's-length importers and low-income countries. Excludes natural resource imports (HS2 categories 1-10 (agricultural products), 25-27 (minerals), and 98 (special classification provisions)). 
Table 8. Firm intermediate-good imports from low-income countries as a share of sales (\%), by importing industry and year, arm's-length importers only

\begin{tabular}{lllll}
\hline \multicolumn{1}{c}{ Description } & $\mathbf{1 9 9 7}$ & $\mathbf{2 0 0 2}$ & $\mathbf{2 0 0 7}$ & $\mathbf{2 0 1 2}$ \\
\hline Food & 0.224 & 0.186 & 0.218 & 0.266 \\
Beverage and Tobacco & 0.116 & 0.073 & 0.098 & 0.124 \\
Textile Mills & 1.431 & 1.445 & 1.963 & 2.814 \\
Textile Product Mills & 0.573 & 0.842 & 1.424 & 1.862 \\
Apparel & 0.253 & 0.329 & 0.396 & 0.726 \\
Leather & 0.279 & 0.353 & 1.278 & 1.424 \\
Wood & 0.276 & 0.652 & 1.500 & 1.236 \\
Paper & 0.160 & 0.267 & 0.458 & 0.490 \\
Printing and Related & 0.184 & 0.088 & 0.352 & 0.970 \\
Petroleum and Coal & 0.137 & 0.012 & 0.021 & 0.143 \\
Chemical & 0.631 & 0.581 & 0.784 & 1.536 \\
Plastics and Rubber & 0.215 & 0.434 & 1.145 & 1.346 \\
Nonmetallic Mineral & 0.179 & 0.521 & 1.052 & 1.190 \\
Primary Metal & 0.172 & 0.152 & 1.794 & 0.801 \\
Fabricated Metal & 0.279 & 0.561 & 1.150 & 1.805 \\
Machinery & 0.119 & 0.355 & 0.675 & 1.129 \\
Computer and Electronic & 0.352 & 0.494 & 0.718 & 1.945 \\
Electrical Equipment & 0.588 & 1.169 & 1.817 & 1.929 \\
Transportation Equipment & 0.157 & 0.270 & 0.807 & 1.378 \\
Furniture & 0.173 & 0.495 & 1.475 & 2.817 \\
Miscellaneous & 0.340 & 0.821 & 1.756 & 2.376 \\
\hline
\end{tabular}

Notes: This table displays industry averages of low-income country intermediate-good imports as a share of total sales by 3-digit NAICS categories. See text for a definition of arm's-length importers and low-income countries. Excludes natural resource imports (HS2 categories 1-10 (agricultural products), 25-27

(minerals), and 98 (special classification provisions)). 
Table 9. Imports from low-income countries as a share of domestic absorption (\%), by industry and year

\begin{tabular}{lcccc}
\hline \multicolumn{1}{c}{ Description } & $\mathbf{1 9 9 7}$ & $\mathbf{2 0 0 2}$ & $\mathbf{2 0 0 7}$ & $\mathbf{2 0 1 2}$ \\
\hline Food & 1.248 & 1.090 & 1.841 & 2.507 \\
Beverage and Tobacco & 0.323 & 0.437 & 0.367 & 0.200 \\
Textile Mills & 6.037 & 8.746 & 16.601 & 24.350 \\
Textile Product Mills & 12.667 & 24.484 & 44.436 & 53.191 \\
Apparel & 22.645 & 30.331 & 58.158 & 75.248 \\
Leather & 49.162 & 62.870 & 73.372 & 83.485 \\
Wood & 2.115 & 2.758 & 5.525 & 6.451 \\
Paper & 1.123 & 2.524 & 6.564 & 7.468 \\
Printing and Related & 0.628 & 1.666 & 3.520 & 4.074 \\
Petroleum and Coal & 0.406 & 0.027 & 0.240 & 0.306 \\
Chemical & 2.629 & 2.731 & 6.388 & 10.482 \\
Plastics and Rubber & 6.208 & 10.005 & 9.254 & 11.481 \\
Nonmetallic Mineral & 3.919 & 6.738 & 8.299 & 11.562 \\
Primary Metal & 2.116 & 3.566 & 8.409 & 6.050 \\
Fabricated Metal & 1.677 & 3.912 & 6.761 & 8.554 \\
Machinery & 3.022 & 6.119 & 13.021 & 14.515 \\
Computer and Electronic & 8.827 & 17.505 & 35.474 & 52.053 \\
Electrical Equipment & 11.040 & 18.925 & 25.479 & 31.298 \\
Transportation Equipment & 0.500 & 0.923 & 3.274 & 4.300 \\
Furniture & 3.911 & 11.654 & 20.150 & 12.151 \\
Miscellaneous & 14.216 & 15.541 & 23.205 & 18.056 \\
\hline
\end{tabular}

Notes: This table displays the imports from low-income countries as a share of domestic absorption by 3-digit NAICS categories. Excludes natural resource imports (HS2 categories 1-10 (agricultural products), 25-27 (minerals), and 98 (special classification provisions)). 
Table 10. Manufacturing employment and wages and firm offshoring, arm's length importers

\begin{tabular}{|c|c|c|c|c|c|c|}
\hline Five Year Change in Log: & $\begin{array}{c}(1) \\
\text { Total } \\
\text { Employment }\end{array}$ & $\begin{array}{c}(2) \\
\text { Manufacturing } \\
\text { Employment }\end{array}$ & $\begin{array}{c}\text { (3) } \\
\text { Non Production } \\
\text { Employment }\end{array}$ & $\begin{array}{c}(4) \\
\text { Production } \\
\text { Employment }\end{array}$ & $\begin{array}{c}\text { (5) } \\
\text { Wage Bill } \\
\text { Ratio }\end{array}$ & $\begin{array}{c}\text { (6) } \\
\text { Production } \\
\text { Wage Rate }\end{array}$ \\
\hline Change in OFF_LI & $\begin{array}{c}-0.0003 \\
(0.0002)\end{array}$ & $\begin{array}{c}-0.0087^{* * *} \\
(0.0008)\end{array}$ & $\begin{array}{c}-0.0079^{* * *} \\
(0.0007)\end{array}$ & $\begin{array}{c}-0.0088^{* * *} \\
(0.0010)\end{array}$ & $\begin{array}{c}0.0001 \\
(0.0001)\end{array}$ & $\begin{array}{l}-0.0007^{* *} \\
(0.0003)\end{array}$ \\
\hline Change in OFF_OTH & $\begin{array}{l}-0.0005^{*} \\
(0.0003)\end{array}$ & $\begin{array}{c}0.0004 \\
(0.0006)\end{array}$ & $\begin{array}{c}0.0004 \\
(0.0006)\end{array}$ & $\begin{array}{c}0.0005 \\
(0.0006)\end{array}$ & $\begin{array}{l}-0.0003^{* * *} \\
(0.0001)\end{array}$ & $\begin{array}{l}0.0007^{* * *} \\
(0.0002)\end{array}$ \\
\hline Log Age & $\begin{array}{l}-0.0913^{* * *} \\
(0.0039)\end{array}$ & $\begin{array}{l}-0.0690^{* * *} \\
(0.0039)\end{array}$ & $\begin{array}{l}-0.0426^{* * *} \\
(0.0055)\end{array}$ & $\begin{array}{l}-0.0433^{* * *} \\
(0.0062)\end{array}$ & $\begin{array}{l}-0.0429^{* * *} \\
(0.0073)\end{array}$ & $\begin{array}{l}0.0118^{* * *} \\
(0.0032)\end{array}$ \\
\hline Log TFP & $\begin{array}{l}0.0463^{* * *} \\
(0.0065)\end{array}$ & $\begin{array}{l}0.0636^{* * *} \\
(0.0110)\end{array}$ & $\begin{array}{l}0.0389^{* * *} \\
(0.0098)\end{array}$ & $\begin{array}{l}0.0813^{* * *} \\
(0.0122)\end{array}$ & $\begin{array}{l}0.0375^{* * *} \\
(0.0110)\end{array}$ & $\begin{array}{l}-0.0028 \\
(0.0052)\end{array}$ \\
\hline Log Employment & $\begin{array}{c}-0.0773^{* * *} \\
(0.0089)\end{array}$ & & & & & \\
\hline Log Mfg. Employment & & $\begin{array}{l}-0.1094^{* * *} \\
(0.0105)\end{array}$ & & & & \\
\hline Log Non Production Employment & & & $\begin{array}{l}-0.2047^{* * *} \\
(0.0086)\end{array}$ & & & \\
\hline Log Production Employment & & & & $\begin{array}{l}-0.1433^{* * *} \\
(0.0136)\end{array}$ & & \\
\hline Log NP/P Wage Ratio & & & & & $\begin{array}{c}-0.4223^{* * *} \\
(0.0213)\end{array}$ & \\
\hline Log Production Wage Rate & & & & & & $\begin{array}{c}-0.5759^{* * *} \\
(0.0169)\end{array}$ \\
\hline $\begin{array}{l}\text { Observations } \\
\text { Fixed Effect }\end{array}$ & & & $\begin{array}{r}57,000 \\
\text { Time Intel }\end{array}$ & & & \\
\hline
\end{tabular}


Table 11. Manufacturing employment and wage and firm narrow offshoring, arm's length importers

\begin{tabular}{|c|c|c|c|c|c|c|}
\hline Five Year Change in Log: & $\begin{array}{c}(1) \\
\text { Total } \\
\text { Employment }\end{array}$ & $\begin{array}{c}\text { (2) } \\
\text { Manufacturing } \\
\text { Employment }\end{array}$ & $\begin{array}{c}(3) \\
\text { Non Production } \\
\text { Employment }\end{array}$ & $\begin{array}{c}\text { (4) } \\
\text { Production } \\
\text { Employment }\end{array}$ & $\begin{array}{c}\text { (5) } \\
\text { Wage Bill Ratio }\end{array}$ & $\begin{array}{c}\quad(6) \\
\text { Production } \\
\text { Wage Rate }\end{array}$ \\
\hline Change in OFF_INT_LI & $\begin{array}{c}-0.0469^{* *} \\
(0.0194)\end{array}$ & $\begin{array}{c}-0.1533^{* * *} \\
(0.0316)\end{array}$ & $\begin{array}{c}-0.1435^{* * *} \\
(0.0338)\end{array}$ & $\begin{array}{c}-0.1700^{* * *} \\
(0.0358)\end{array}$ & $\begin{array}{c}0.0170 \\
(0.0272)\end{array}$ & $\begin{array}{c}-0.0293^{* *} \\
(0.0105)\end{array}$ \\
\hline Change in OFF_INT_OTH & $\begin{array}{l}0.0092^{* *} \\
(0.0039)\end{array}$ & $\begin{array}{c}0.0303^{* * *} \\
(0.0064)\end{array}$ & $\begin{array}{c}0.0285^{* * *} \\
(0.0069)\end{array}$ & $\begin{array}{c}0.0338^{* * *} \\
(0.0073)\end{array}$ & $\begin{array}{c}-0.0038 \\
(0.0055)\end{array}$ & $\begin{array}{c}0.0065^{* * *} \\
(0.0021)\end{array}$ \\
\hline Log Age & $\begin{array}{c}-0.0913^{* * *} \\
(0.0039)\end{array}$ & $\begin{array}{c}-0.0689^{* * *} \\
(0.0039)\end{array}$ & $\begin{array}{c}-0.0425^{* * *} \\
(0.0055)\end{array}$ & $\begin{array}{c}-0.0433^{* * *} \\
(0.0062)\end{array}$ & $\begin{array}{c}-0.0429^{* * *} \\
(0.0073)\end{array}$ & $\begin{array}{c}0.0117^{* * *} \\
(0.0032)\end{array}$ \\
\hline Log TFP & $\begin{array}{c}0.0465^{* * *} \\
(0.0065)\end{array}$ & $\begin{array}{c}0.0636^{* * *} \\
(0.0110)\end{array}$ & $\begin{array}{c}0.0390^{* * *} \\
(0.0099)\end{array}$ & $\begin{array}{c}0.0813^{* * *} \\
(0.0122)\end{array}$ & $\begin{array}{c}0.0374^{* * *} \\
(0.0109)\end{array}$ & $\begin{array}{c}-0.0027 \\
(0.0052)\end{array}$ \\
\hline Log Employment & $\begin{array}{c}-0.0773^{* * *} \\
(0.0089)\end{array}$ & & & & & \\
\hline Log Mfg. Employment & & $\begin{array}{c}-0.1097^{* * *} \\
(0.0105)\end{array}$ & & & & \\
\hline Log Non Prod Employment & & & $-0.2050^{* * *}$ & & & \\
\hline Log Prod Employment & & & & $\begin{array}{c}-0.1435^{* * *} \\
(0.0136)\end{array}$ & & \\
\hline Log NP/P Wage Ratio & & & & & $\begin{array}{c}-0.4223^{* * *} \\
(0.0214)\end{array}$ & \\
\hline Log Prod Wage Rate & & & & & & $\begin{array}{c}-0.5760^{* * *} \\
(0.0169) \\
\end{array}$ \\
\hline Observations & \multicolumn{6}{|c|}{57,000} \\
\hline Fixed Effect & & & Time & terval & & \\
\hline
\end{tabular}


Table 12. Manufacturing employment and wages, firm offshoring and import competition, arm's length importers

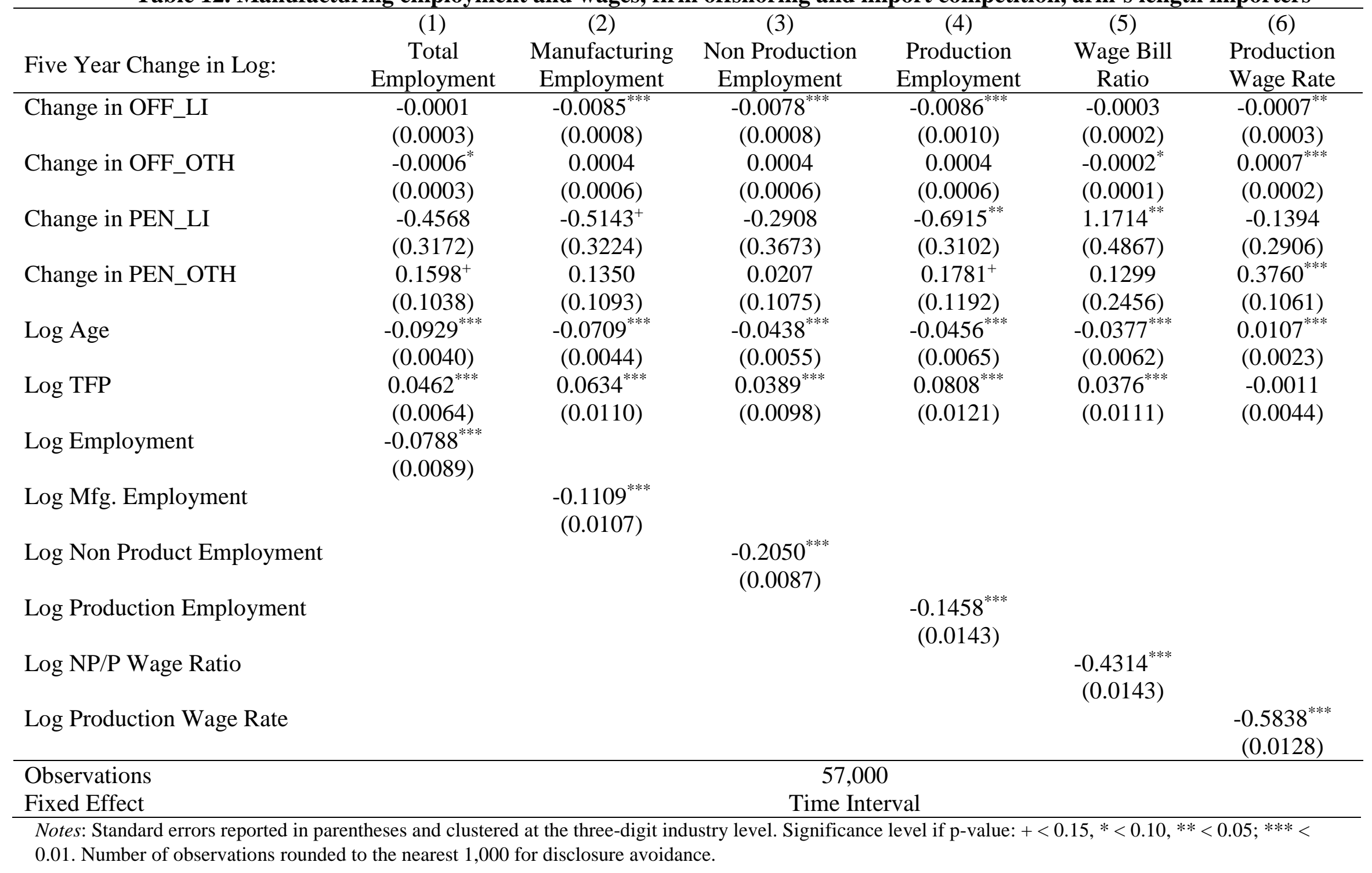


Table 13. Manufacturing employment and wages, narrow offshoring, and import competition, arm's length importers

\begin{tabular}{|c|c|c|c|c|c|c|}
\hline Five Year Change in Log: & $\begin{array}{c}\text { (1) } \\
\text { Total } \\
\text { Employment }\end{array}$ & $\begin{array}{c}(2) \\
\text { Manufacturing } \\
\text { Employment }\end{array}$ & $\begin{array}{c}(3) \\
\text { Non Production } \\
\text { Employment }\end{array}$ & $\begin{array}{c}\text { (4) } \\
\text { Production } \\
\text { Employment }\end{array}$ & $\begin{array}{c}\text { (5) } \\
\text { Wage Bill Ratio }\end{array}$ & $\begin{array}{c}\text { (6) } \\
\text { Production } \\
\text { Wage Rate }\end{array}$ \\
\hline Change in OFF_INT_LI & $\begin{array}{c}-0.0463^{* *} \\
(0.0184)\end{array}$ & $\begin{array}{c}-0.1528^{* * *} \\
(0.0295)\end{array}$ & $\begin{array}{c}-0.1432^{* * *} \\
(0.0328)\end{array}$ & $\begin{array}{c}-0.1693^{* * *} \\
(0.0332)\end{array}$ & $\begin{array}{c}0.0149 \\
(0.0251)\end{array}$ & $\begin{array}{c}-0.0295^{* * *} \\
(0.0101)\end{array}$ \\
\hline Change in OFF_INT_OTH & $\begin{array}{l}0.0090^{* *} \\
(0.0037)\end{array}$ & $\begin{array}{l}0.0302^{* * *} \\
(0.0060)\end{array}$ & $\begin{array}{c}0.0284^{* * *} \\
(0.0067)\end{array}$ & $\begin{array}{l}0.0336^{* * *} \\
(0.0068)\end{array}$ & $\begin{array}{l}-0.0033 \\
(0.0051)\end{array}$ & $\begin{array}{l}0.0065^{* * *} \\
(0.0021)\end{array}$ \\
\hline Change in PEN_LI & $\begin{array}{l}-0.4566 \\
(0.3167)\end{array}$ & $\begin{array}{l}-0.5183^{+} \\
(0.3225)\end{array}$ & $\begin{array}{l}-0.2942 \\
(0.3678)\end{array}$ & $\begin{array}{l}-0.6955^{* *} \\
(0.3098)\end{array}$ & $\begin{array}{l}1.1711^{* *} \\
(0.4866)\end{array}$ & $\begin{array}{l}-0.1396 \\
(0.2904)\end{array}$ \\
\hline Change in PEN_OTH & $\begin{array}{c}0.1599^{+} \\
(0.1038)\end{array}$ & $\begin{array}{c}0.1360 \\
(0.1093)\end{array}$ & $\begin{array}{c}0.0219 \\
(0.1074)\end{array}$ & $\begin{array}{l}0.1791^{+} \\
(0.1192)\end{array}$ & $\begin{array}{c}0.1299 \\
(0.2456)\end{array}$ & $\begin{array}{c}0.3762^{* * *} \\
(0.1061)\end{array}$ \\
\hline Log Age & $\begin{array}{c}-0.0929^{* * *} \\
(0.0040)\end{array}$ & $\begin{array}{c}-0.0709^{* * *} \\
(0.0044)\end{array}$ & $\begin{array}{c}-0.0438^{* * *} \\
(0.0055)\end{array}$ & $\begin{array}{c}-0.0456^{* * *} \\
(0.0065)\end{array}$ & $\begin{array}{c}-0.0377^{* * *} \\
(0.0062)\end{array}$ & $\begin{array}{l}0.0107^{* * *} \\
(0.0023)\end{array}$ \\
\hline Log TFP & $\begin{array}{l}0.0463^{* * *} \\
(0.0064)\end{array}$ & $\begin{array}{l}0.0634^{* * *} \\
(0.0110)\end{array}$ & $\begin{array}{l}0.0389^{* * *} \\
(0.0099)\end{array}$ & $\begin{array}{l}0.0809^{* * *} \\
(0.0121)\end{array}$ & $\begin{array}{l}0.0376^{* * *} \\
(0.0110)\end{array}$ & $\begin{array}{l}-0.0011 \\
(0.0044)\end{array}$ \\
\hline Log Employment & $\begin{array}{c}-0.0788^{* * *} \\
(0.0089)\end{array}$ & & & & & \\
\hline Log Mfg. Employment & & $\begin{array}{c}-0.1111^{* * *} \\
(0.0107)\end{array}$ & & & & \\
\hline Log Non Prod Employment & & & $\begin{array}{c}-0.2053^{* * *} \\
(0.0087)\end{array}$ & & & \\
\hline Log Prod Employment & & & & $\begin{array}{c}-0.1461^{* * *} \\
(0.0143)\end{array}$ & & \\
\hline Log NP/P Wage Ratio & & & & & $\begin{array}{c}-0.4314^{* * *} \\
(0.0143)\end{array}$ & \\
\hline Log Production Wage Rate & & & & & & $\begin{array}{c}-0.5839^{* * *} \\
(0.0128)\end{array}$ \\
\hline $\begin{array}{l}\text { Observations } \\
\text { Fixed Effect }\end{array}$ & & & $\begin{array}{r}57,00 \\
\text { Time Int }\end{array}$ & Jal & & \\
\hline
\end{tabular}


Table 14. Manufacturing employment and wages and import competition, non-trading firms

\begin{tabular}{|c|c|c|c|c|c|c|}
\hline Five Year Change in Log: & $\begin{array}{c}(1) \\
\text { Total } \\
\text { Employment }\end{array}$ & $\begin{array}{c}(2) \\
\text { Manufacturing } \\
\text { Employment }\end{array}$ & $\begin{array}{c}(3) \\
\text { Non Production } \\
\text { Employment }\end{array}$ & $\begin{array}{c}\text { (4) } \\
\text { Production } \\
\text { Employment }\end{array}$ & $\begin{array}{c}(5) \\
\text { Wage Bill } \\
\text { Ratio }\end{array}$ & $\begin{array}{c}\quad(6) \\
\text { Production } \\
\text { Wage Rate }\end{array}$ \\
\hline Change in PEN_LI & $\begin{array}{c}-0.2978 \\
(0.4566)\end{array}$ & $\begin{array}{c}-0.2990 \\
(0.4924)\end{array}$ & $\begin{array}{l}-0.3363 \\
(0.4216)\end{array}$ & $\begin{array}{c}-0.3508 \\
(0.5277)\end{array}$ & $\begin{array}{c}0.0722 \\
(0.3314)\end{array}$ & $\begin{array}{l}-0.2686 \\
(0.2937)\end{array}$ \\
\hline Change in PEN_OTH & $\begin{array}{c}0.2238 \\
(0.2390)\end{array}$ & $\begin{array}{c}0.0826 \\
(0.3112)\end{array}$ & $\begin{array}{l}-0.0036 \\
(0.2648)\end{array}$ & $\begin{array}{l}-0.0158 \\
(0.3632)\end{array}$ & $\begin{array}{l}-0.1693 \\
(0.3236)\end{array}$ & $\begin{array}{l}0.6580^{* *} \\
(0.2875)\end{array}$ \\
\hline Log Age & $\begin{array}{c}-0.0679^{* * *} \\
(0.0047)\end{array}$ & $\begin{array}{c}-0.0547^{* * *} \\
(0.0054)\end{array}$ & $\begin{array}{c}-0.0233^{* * *} \\
(0.0052)\end{array}$ & $\begin{array}{c}-0.0457^{* * *} \\
(0.0067)\end{array}$ & $\begin{array}{c}0.0043 \\
(0.0052)\end{array}$ & $\begin{array}{l}0.0104^{* * *} \\
(0.0018)\end{array}$ \\
\hline Log TFP & $\begin{array}{c}0.0132^{* * *} \\
(0.0042)\end{array}$ & $\begin{array}{c}0.0509^{* * *} \\
(0.0050)\end{array}$ & $\begin{array}{l}0.0172^{* *} \\
(0.0082)\end{array}$ & $\begin{array}{l}0.0837^{* * *} \\
(0.0091)\end{array}$ & $\begin{array}{c}0.0208^{*} \\
(0.0109)\end{array}$ & $\begin{array}{c}-0.0258^{* * *} \\
(0.0057)\end{array}$ \\
\hline Log Employment & $\begin{array}{c}-0.1088^{* * *} \\
(0.0127)\end{array}$ & & & & & \\
\hline Log Mfg. Employment & & $\begin{array}{c}-0.1366^{* * *} \\
(0.0122)\end{array}$ & & & & \\
\hline Log Non Production Employment & & & $\begin{array}{c}-0.2983^{* * *} \\
(0.0099)\end{array}$ & & & \\
\hline Log Production Employment & & & & $\begin{array}{c}-0.1770^{* * *} \\
(0.0114)\end{array}$ & & \\
\hline Log NP/P Wage Ratio & & & & & $\begin{array}{c}-0.5217^{* * *} \\
(0.0179)\end{array}$ & \\
\hline Log Production Wage Rate & & & & & & $\begin{array}{c}-0.5933^{* * *} \\
(0.0327)\end{array}$ \\
\hline Observations & & & 115 & & & \\
\hline Fixed Effect & & & Time Ir & rval & & \\
\hline
\end{tabular}


A. Low-Income Country Import Index (LCI) and Other Source Import Index (OTHI)

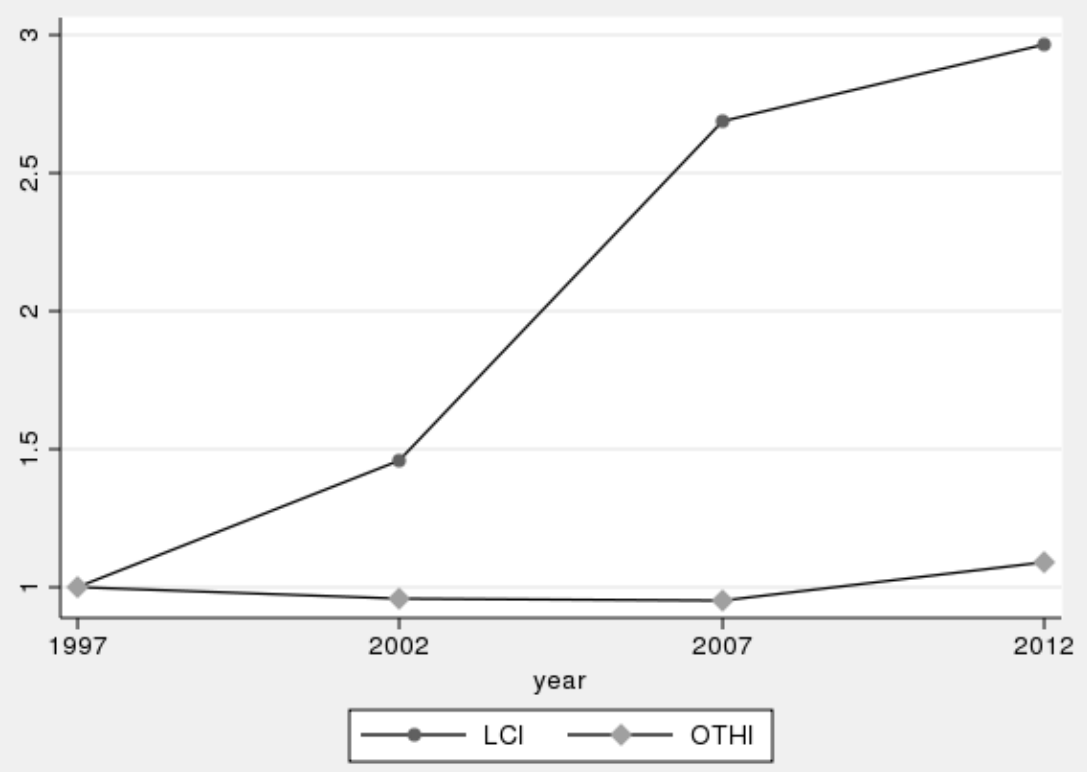

B. Low-Income Country Intermediate Imports Index (LCINT) and Other Source Intermediate Imports Index (OTHINT)

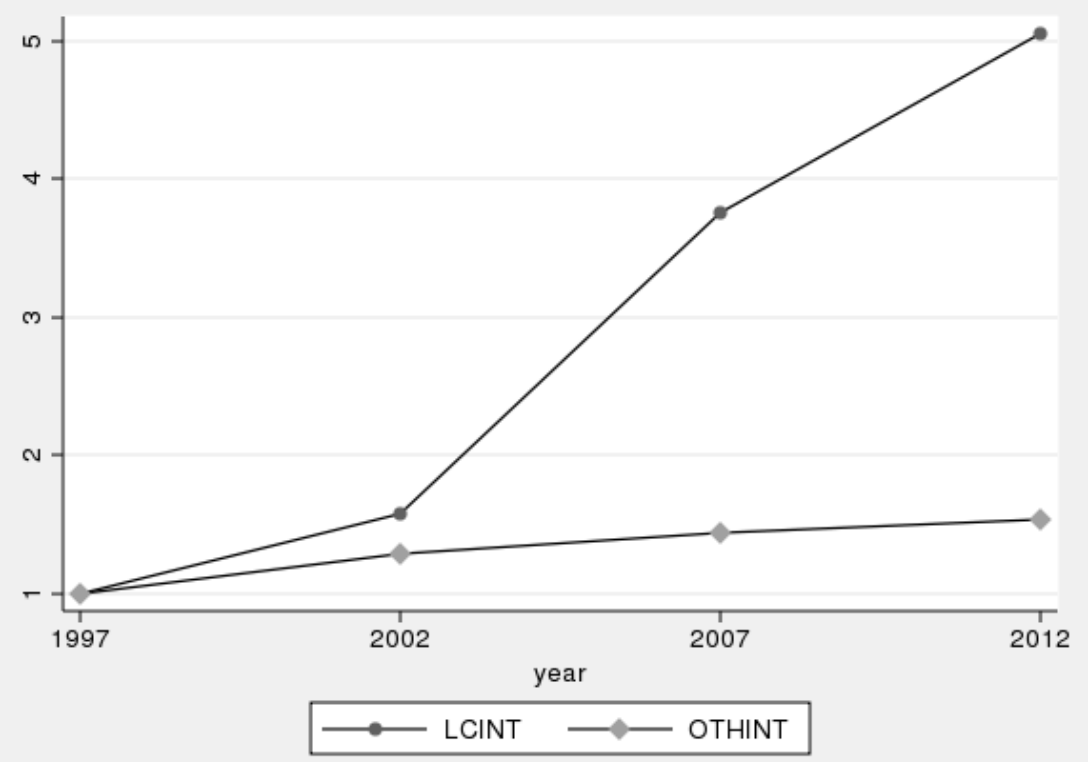

Notes: These figures are based on annual averages of firm-level import measures, calculated for the sample of arm's length importers. Values expressed relative to 1997 value. The firm level import shares are aggregated at the 3-digit NAICS level and then averaged over time. $I_{j t}=\sum_{j} \frac{\text { Imports }_{i j t}^{c}}{\text { Sales }_{i j t}}$ and $I N T_{i t}=\sum_{j} \frac{\text { Intermediate Imports }_{i j t}^{c}}{\text { Sales }_{i j t}}$, where $j$ is industry and $c$ country group. 
Figure 2. US import penetration indices, annual averages

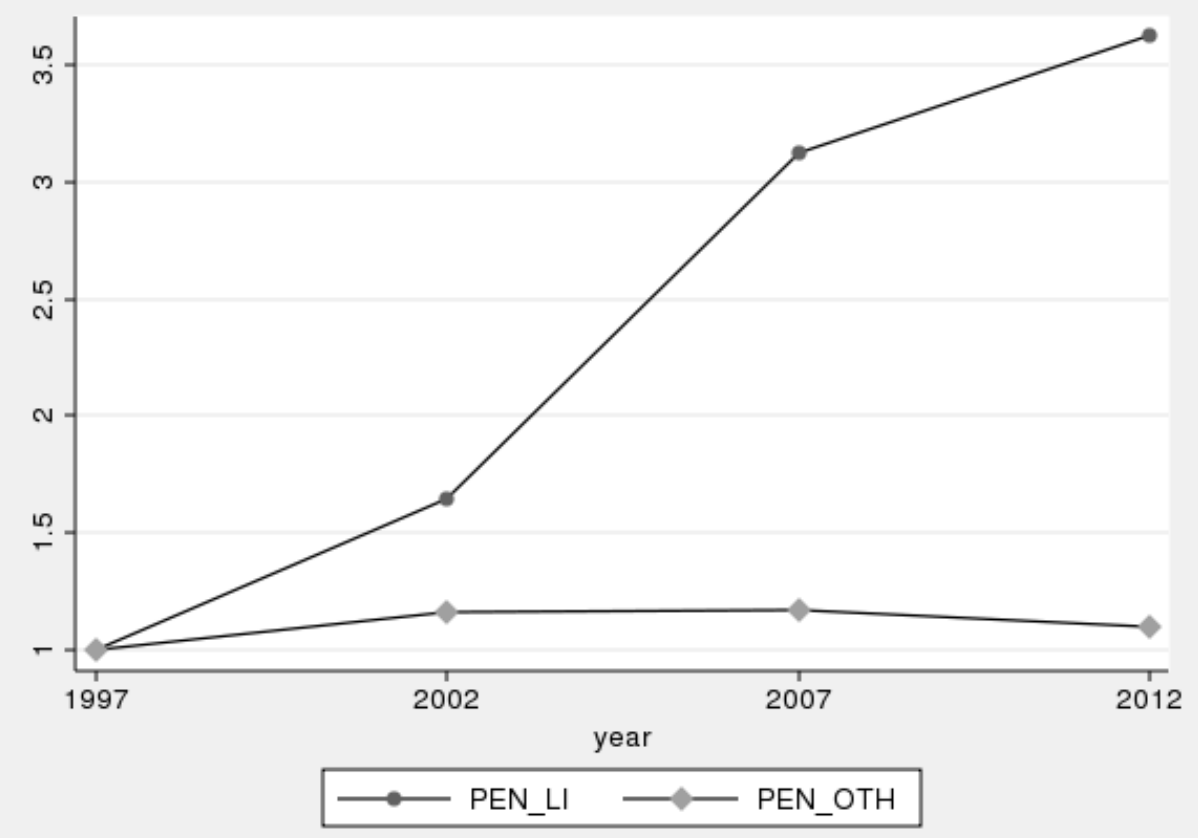

Notes: This figure displays annual averages of total imports from low income countries (PEN_LI) and other countries (PEN_OTH ), respectively, as a share of domestic absorption. Values expressed relative to 1997 value. See text for index construction details. 
Table A1: Low Income Countries Used to Create Trade Measures

\begin{tabular}{|c|c|c|c|}
\hline Albania & Cote d'Ivoire & Kiribati & Republic of Congo \\
\hline Angola & Democratic Republic of Congo & Kyrgyzstan & Romania \\
\hline Armenia & Djibouti & Laos & Rwanda \\
\hline Azerbaijan & Egypt & Lesotho & Senegal \\
\hline Bangladesh & Equatorial Guinea & Liberia & Sierra Leone \\
\hline Belarus & Eritrea & Madagascar & Solomon Islands \\
\hline Benin & Ethiopia & Malawi & Sri Lanka \\
\hline Bhutan & Gambia & Mali & Sudan \\
\hline Bolivia & Gaza Strip & Mauritania & Syria \\
\hline Bosnia and Herzegovina & Georgia & Moldova & Tajikistan \\
\hline Bulgaria & Ghana & Mongolia & Tanzania \\
\hline Burkina Faso & Guinea & Morocco & Togo \\
\hline Burundi & Guinea-Bissau & Mozambique & Turkmenistan \\
\hline Cabo Verde & Guyana & Nepal & Tuvalu \\
\hline Cambodia & Haiti & Nicaragua & Uganda \\
\hline Cameroon & Honduras & Niger & Ukraine \\
\hline Central African Republic & India & Nigeria & Uzbekistan \\
\hline Chad & Indonesia & Pakistan & Vanuatu \\
\hline China & Kazakhstan & Papua New Guinea & Vietnam \\
\hline Comoros & Kenya & Philippines & Yemen \\
\hline
\end{tabular}

Notes: This table shows the countries identified as low income as of 1997. A country is classified as low income in 1997 if its GDP per capita is less than 5 percent of U.S. per capita GDP. *Administered by Israel. 